BEN S. BERNANKE

Princeton University

JOHN Y. CAMPBELL

Princeton University

\title{
Is There a \\ Corporate Debt Crisis?
}

CONCERN about the financial stability of the U.S. corporate sector has been a staple of the business press and, to a lesser extent, of academic research for years. Henry Kaufman has been particularly consistent in warning about the dangers of excessive debt, in the household and government sectors as well as in corporations. His most recent article stresses the rapid growth of debt relative to income, as well as deteriorating credit quality. ${ }^{1}$

Table 1 presents statistics on U.S. corporate debt growth and national income since 1969. The first two columns give the average growth rates of nominal GNP and the book value of outstanding nonfinancial corporate debt, as reported by the Flow of Funds, for the period 1969-80 and for each year in the eighties; Kaufman cites similar figures, although with different sample periods. The final four columns include, for comparison, related series from a sample of 643 COMPUSTAT firms.

The table suggests that if there is any problem with the rate of debt growth, it has developed recently. ${ }^{2}$ While debt growth and income

We are grateful to Gordon Bodnar and Toni Whited for able and dedicated research assistance, and to members of the Brookings Panel for helpful comments on an earlier draft.

1. Henry Kaufman, "Debt: The Threat to Economic and Financial Stability," in Federal Reserve Bank of Kansas City, Debt, Financial Stability, and Public Policy (FRBKC, 1986), pp. 15-26. For a popular article with a similar emphasis, see Lindley H. Clark, Jr., and Alfred L. Malabre, Jr., "Borrowing Binge: Takeover Trend Helps Push Corporate Debt and Defaults Upward," Wall Street Journal, March 15, 1988.

2. Our sample covers only the past two decades. In a broader historical perspective, 
Table 1. Growth Rates of U.S. Nonfinancial Corporate Debt and Related Series, 1969-86

Percent per year

\begin{tabular}{lcccccc}
\hline & & \multicolumn{4}{c}{ Fixed sample of COMPUSTAT firms } \\
\cline { 3 - 7 } & & & \multicolumn{5}{c}{$\begin{array}{c}\text { Book- } \\
\text { value } \\
\text { Year }\end{array}$} & $\begin{array}{c}\text { Nominal } \\
\text { GNP }\end{array}$ & $\begin{array}{c}\text { Corporate } \\
\text { debt }\end{array}$ & Sales & $\begin{array}{c}\text { Gross } \\
\text { income }\end{array}$ & Interest \\
\hline $1969-80$ & 9.5 & 9.4 & 13.2 & 12.8 & 8.4 & 14.4 \\
1981 & 11.1 & 10.3 & 8.6 & 3.9 & 11.3 & 23.2 \\
1982 & 3.7 & 7.2 & -2.3 & -15.9 & 8.3 & 7.7 \\
1983 & 7.3 & 5.1 & 1.9 & 9.7 & -2.0 & -4.6 \\
1984 & 10.2 & 15.7 & 8.2 & 17.5 & 9.9 & 9.2 \\
1985 & 6.1 & 12.0 & 2.0 & -13.6 & 12.2 & 5.7 \\
1986 & 5.5 & 11.9 & -3.0 & -6.8 & 9.9 & 6.4 \\
\hline
\end{tabular}

Sources: All figures are annual percent changes, calculated as differences in natural logarithms. Nominal GNP is from the National Income and Product Accounts. Corporate debt is total credit market instruments (book value) of nonfinancial corporations from Board of Governors of the Federal Reserve System, "Balance Sheets for the U.S. Economy, 1946-85" (Federal Reserve Board Release C.9, 1986) and "Flow of Funds Accounts," various issues. Sales, gross income, book debt, and interest are from the COMPUSTAT Industrial and Research data files. COMPUSTAT series are calculated for the fixed sample of 643 firms that have all data available for 1969-86; dollar values are summed across firms, and growth rates are then calculated for the total.

a. After-tax operating income plus income taxes and interest paid.

growth were similar during the 1970s, in 1984-86 nonfinancial corporate debt outgrew nominal GNP by about 18 percentage points. Sales and income growth were much more erratic in the sample of COMPUSTAT firms, but the same point is there: after growing more slowly than income during 1969-80, debt and debt service expanded much more quickly than income and sales in the eighties, notably during 1981-82 and 1985-86. ${ }^{3}$

A point made by Kaufman and particularly emphasized by Benjamin Friedman is that the increase in corporate debt during the 1980 s has been related to financial reorganization and takeover activity. ${ }^{4}$ The shifts in

corporate debt during the 1970s and 1980s has been higher than it was during the 1950s and 1960s, but comparable to debt levels in earlier periods such as the 1920s. See Robert A. Taggart, Jr., "Secular Patterns in the Financing of U.S. Corporations," in Benjamin M. Friedman, ed., Corporate Capital Structures in the United States (University of Chicago Press, 1985), pp. 13-75.

3. The negative growth rates of sales in 1986 and gross income in 1985 and 1986 appear to be due in part to the presence of oil companies in the sample. When we eliminate petroleum and natural gas (SIC industry 13) and petroleum refining (SIC industry 29) from the sample, the growth rates of sales and gross income become positive in 1986, although the growth rate for gross income remains negative in 1985. Below we present some results for the sample excluding the two oil-related industries.

4. Benjamin M. Friedman, "Increasing Indebtedness and Financial Stability in the United States," in Federal Reserve Bank of Kansas City, Debt, Financial Stability, and Public Policy, pp. 27-53. 
aggregate financial structure do appear to have been large recently. To quote Kaufman: "Over the two years 1984 and 1985, the debt of nonfinancial corporations rose by $\$ 384$ billion, while equity contracted by $\$ 99$ billion. This contraction comprises the total of retained earnings, which were a positive $\$ 53$ billion, and net new equity issuance, which was a negative $\$ 152$ billion." 5 Kaufman has characterized this widespread substitution of debt for equity as an "audacious levering strategy."

The pattern of substituting debt for equity is apparent in the sample of 643 COMPUSTAT firms introduced in table 1 as well. Table 2 gives the sources and uses of funds for these firms annually for 1969-86. Sources are defined as after-tax earnings and net debt issue. Uses are net equity repurchases, dividends, and "other." The "other" category, which should reflect financial and real investments made by firms, is calculated as a residual.

The most striking feature of the table is the recent break in the pattern of equity repurchases. Until 1984 the firms in the sample issued small net amounts of equity each year. During 1984-86, however, they repurchased large quantities of equity. These repurchases appear to have been financed in part by new debt issue and in part by reduced real and financial investment by corporations. ${ }^{6}$

These aggregate numbers suggest that the rise of corporate debt during the 1980s may have been unusual. But the statistics are not definitive. First, these debt series are based on book-value measures, not on economically more significant market values. Second, debt outstanding can be judged high or low only relative to the assets that support it. Finally, aggregate debt measures tell nothing about the distribution of debt burdens across firms. Yet for anyone who is concerned about the implications of an aggregate shock for bankruptcy rates or financial distress, the debt burdens of firms in the upper "tail" of the distribution are more important than average measures.

The primary purpose of this paper is to investigate empirically the

5. Kaufman, "Debt: The Threat to Economic and Financial Stability," p. 18.

6. In this discussion we have followed Kaufman and others in emphasizing repurchases over dividends. When debt-asset ratios are calculated at book values, repurchases reduce outstanding equity while dividends do not. In corporate financial theory, however, repurchases and dividends are thought of symmetrically as cash payments made by corporations to shareholders. Repurchases may have tax advantages, but otherwise do not differ from dividends. In particular, they do not lower the market value of equity beyond the usual drop when a dividend payment is made. 
Table 2. Sources and Uses of Funds, Fixed Sample of Firms, 1969-86

Billions of current dollars

\begin{tabular}{|c|c|c|c|c|c|}
\hline \multirow[b]{2}{*}{ Year } & \multicolumn{2}{|c|}{ Sources } & \multicolumn{3}{|c|}{ Uses } \\
\hline & $\begin{array}{l}\text { After-tax } \\
\text { earnings }\end{array}$ & $\begin{array}{c}\text { Net debt } \\
\text { issue }\end{array}$ & $\begin{array}{l}\text { Net equity } \\
\text { repurchase }\end{array}$ & $\begin{array}{c}\text { Total } \\
\text { dividends }\end{array}$ & Other ${ }^{\mathrm{a}}$ \\
\hline 1969 & 16.6 & 14.8 & 0.0 & 8.6 & 22.8 \\
\hline 1970 & 15.7 & 12.9 & 0.0 & 8.9 & 19.7 \\
\hline 1971 & 17.2 & 5.8 & -2.1 & 9.1 & 16.0 \\
\hline 1972 & 20.2 & 5.9 & -1.3 & 9.4 & 18.0 \\
\hline 1973 & 26.8 & 11.9 & -0.5 & 10.2 & 29.0 \\
\hline 1974 & 32.4 & 22.1 & -0.8 & 11.6 & 43.7 \\
\hline 1975 & 28.8 & 5.4 & -1.6 & 12.3 & 23.5 \\
\hline 1976 & 36.0 & 6.4 & -2.9 & 13.7 & 31.6 \\
\hline 1977 & 40.0 & 11.9 & -2.0 & 15.9 & 38.0 \\
\hline 1978 & 44.3 & 20.3 & -2.1 & 18.1 & 48.6 \\
\hline 1979 & 58.1 & 24.1 & -2.9 & 20.8 & 64.3 \\
\hline 1980 & 61.0 & 28.1 & -2.7 & 24.0 & 67.8 \\
\hline 1981 & 63.4 & 30.5 & -6.9 & 26.7 & 74.1 \\
\hline 1982 & 47.6 & 24.6 & -5.7 & 28.0 & 49.9 \\
\hline 1983 & 55.6 & -6.0 & -11.5 & 29.8 & 31.3 \\
\hline 1984 & 69.9 & 31.7 & 8.9 & 31.9 & 60.8 \\
\hline 1985 & 52.9 & 43.6 & 19.6 & 32.9 & 44.0 \\
\hline 1986 & 48.8 & 39.6 & 7.3 & 38.1 & 43.0 \\
\hline
\end{tabular}

Source: COMPUSTAT data base. Tabulations are for the fixed sample of 643 firms that have all data available for 1969-86.

a. Calculated as a residual.

behavior of nonfinancial corporate debt in the United States, especially during recent years. We use COMPUSTAT files, which contain detailed historical data on the balance sheets and income statements of about 2,400 nonfinancial corporations. Of these firms, nearly 1,400 have sufficient data for us to estimate market values of firm debt in each year. We compare market values of debt and assets, both in aggregate and cross-sectionally, to address the question of how the upper tail of the debt-asset distribution has evolved over time. Other measures of liquidity and indicators of solvency, such as the ratio of interest obligations to income, are examined in a similar way.

Because the COMPUSTAT data also allow a breakdown of the results by two-digit industry groups, we are able to investigate the degree to which aggregate increases in debt are related to changes in industry composition, and the extent to which changes in debt levels are concentrated in a few industries or more diffused. Using a panel data set of two- 
digit Standard Industrial Classification (SIC) code industries over the 1969-86 period, we also estimate an equation to capture the determinants of changing debt-asset ratios.

A particular concern is how a major economic shock would affect firms with increased debt burdens. We try to assess whether the stock market crash of October 1987 had different effects on high-debt and lowdebt firms. Using simulations, we also study the hypothetical question of how recessions such as those of 1973-74 and 1981-82 would affect the financial structures of our sample of firms if they took place today.

Before beginning our empirical analysis, we address the issue of why high levels of corporate debt should be of interest to economists, forecasters, and policymakers. Although applied economists seem to believe that the dangers of debt are obvious, the existing theoretical literature offers few explanations.

Our next section briefly discusses this issue. We comment first on the "debt-existence puzzle"- - the question of why in the first place firms choose to use debt as a means of finance. The question is abstract, but it sheds light on the benefits and costs of debt issuance to the individual firm, which we discuss next. We then speculate, based on recent formal research, on the macroeconomic significance of the level of firm debt.

The conclusions of our paper are as follows. From a theoretical perspective, there are reasons to believe that debt levels are not irrelevant, in the Modigliani-Miller sense that firm and economywide performance is independent of financial structure; rather, debt levels should be of concern to policymakers and others. ${ }^{7}$ However, the theoretical case is far from complete and awaits further development. Empirically, the results are mixed. If one believes that the large increases in equity values during the 1980s reflect good estimates of the present value of future corporate earnings, there appears to be little basis for concern. In this view, the postwar "debt crisis," if there was one, occurred in 1974. However, measures of corporate debt burden on a current basis, such as the ratio of interest payments to cash flows, have deteriorated sharply, suggesting possible liquidity problems for the corporate sector. A sharp fall in equity values or some other adverse shock could imply a solvency problem as well. Because policymakers and economic analysts should

7. See Franco Modigliani and Merton Miller, "The Cost of Capital, Corporation Finance, and the Theory of Investment," American Economic Review, vol. 48 (June 1958), pp. 261-97. 
be concerned with worst-case as well as "average" outcomes, our findings in this regard are worrisome.

\section{Why Do We Care about Debt?}

The recent literature on the possibility of an impending corporate debt crisis seems to take it for granted that the aggregate level of debt has macroeconomic significance-in particular, that high levels of debt are dangerous. But why this might be so is not at all an easy question to answer. At the most basic level, it is not even obvious why debt, defined as a claim whose payoff depends on the value of the firm only in the worst circumstances and which is otherwise fixed, exists at all. One could imagine many other arrangements by which firms might obtain funds. In an Arrow-Debreu economy, for example, financing would be done by the sale of fully contingent claims. (Bankruptcy, in the sense of someone not being able to make a promised payoff, cannot occur in an Arrow-Debreu world.) Since it helps provide some insight into why high debt levels may create real costs for firms, we begin with a discussion of the "existence" question. ${ }^{8}$ We then consider both the microeconomic and the macroeconomic consequences of high levels of firm debt.

\section{WHY FIRMS ISSUE DEBT}

One explanation for the existence of debt is debt's tax-favored status. The tax deductibility of most interest payments in the United States creates more debt than there otherwise would be. However, the tax laws do not explain why debt exists in the first place. Many forms of debt were common before the adoption of the income tax. Debt is also common in countries without interest deductibility, and the forms of debt that lost deductibility in the recent U.S. tax reform are not likely to disappear, although their use will be reduced. We therefore put taxes aside and look for more fundamental explanations.

Three reasons for the use of debt in corporate finance are the costliness

8. This question is not usually addressed in the large finance literature on the capital structure puzzle. That literature studies the determination of the firm's optimal combination of debt and equity, given that these are the only types of borrowing instruments available; it does not usually ask whether alternative forms of financial contracts might not dominate both debt and equity. For one exception, see Milton Harris and Artur Raviv, "The Design of Securities" (University of Chicago and Northwestern University, March 1988). 
of making claims contingent upon firms' condition, the incentive effects of debt, and the use of debt as a risk-sharing instrument. All follow from failures of the Arrow-Debreu assumptions that information is perfect and markets are complete, and each will be significant in understanding the possible dangers of a corporate debt crisis.

If it is excessively costly or impossible to distinguish the condition of firms, especially in a legally verifiable way, noncontingent claims such as debt will be attractive. People do in fact seem reluctant to include contingencies on even easily verifiable outcomes in contracts. Witness the slowness with which simple inflation indexing has been incorporated into labor contracts and financial arrangements. An important point, however, is that firms are virtually never able to make their debt fully noncontingent, at least not at customary levels of debt issuance. Conditions can become so unfavorable that the firm cannot make its promised payments. If these "bankruptcy" conditions occur, there must be some mechanism to verify them to the lender; otherwise, the firm would have an incentive always to claim bad luck and avoid paying off. Various such mechanisms exist. One possibility is some sort of auditing process. ${ }^{9}$ Another is some action by the firm to signal unfavorable conditions, such as shutting down operations, that it would not ordinarily find worthwhile to undertake, even if it could reduce debt obligations. ${ }^{10}$ Whatever the mechanism, it must of necessity involve net social costs when it is invoked; if the verification of the firm's condition were free, then a debt contract would not have been desirable in the first place.

A benefit of debt contracts, then, is that they save on the costs of ascertaining a firm's condition when it is relatively good. But when conditions are bad, debt contracts must entail real social costs. Those costs may be called bankruptcy costs, but they should be thought of as covering a wider range of costs than the usual definition of the term. Importantly, expected bankruptcy costs in this sense are higher the higher the expected rate of return demanded by the lender, because the high expected return increases the circumstances in which the firm

$\rightarrow$ Robert M. Townsend, "Optimal Contracts and Competitive Markets with Costly State Verification," Journal of Economic Theory, vol. 21 (October 1979), pp. 265-93; Douglas Gale and Martin Hellwig, "Incentive-Compatible Debt Contracts: The OnePeriod Problem," Review of Economic Studies, vol. 52 (October 1985), pp. 647-64.

10. Sanford J. Grossman and Oliver D. Hart, "Implicit Contracts, Moral Hazard, and Unemployment," American Economic Review, vol. 71 (May 1981, Papers and Proceedings, 1980), pp. 301-07; Roger E. A. Farmer, "A New Theory of Aggregate Supply," American Economic Review, vol. 74 (December 1984), pp. 920-30. 
cannot pay off. They are also higher the lower the initial net worth of the firm, because low net worth allows the firm to pay off under fewer circumstances.

The second reason for debt, which also arises because of a departure from perfect information, is debt's possibly desirable incentive effects on the owners or managers of the firm. ${ }^{11}$ In the simplest case, the owner and manager are the same person and are approximately risk-neutral. If the owner's decisions or level of effort is not fully observable by his suppliers of funds, the optimal form of lending involves fixed (noncontingent) repayment, which forces the owner to bear the full consequences of his actions and thus induces him to make socially optimal decisions.

Strictly speaking, this "first-best" outcome occurs only when the firm-owner has sufficient financial capital to be able to guarantee repayment in every contingency and there is no possibility of bankruptcy; otherwise, as David Sappington has shown, the optimal contract may involve a degree of contingency and will not induce the borrower to take first-best actions. For our purposes, though, the simple principal-agent model suggests two conclusions. First, with low bankruptcy probabilities and low borrower risk aversion, debt contracts have good incentive properties; they induce the owners of the firm to bear most of the consequences of their decisions, and therefore to make better decisions. ${ }^{12}$ Second, as above, lower initial net worth makes a good incentive structure harder to obtain by reducing the range of circumstances over which the firm can offer purely noncontingent debt contracts. ${ }^{13}$

11. The seminal piece in this are $\rightarrow$ Michael C. Jensen and William H. Meckling, "Theory of the Firm: Managerial Behavior, Agency Costs and Capital Structure," Journal of Financial Economics, vol. 3 (October 1976), pp. 305-60. The points of this paragraph are formalize $\rightarrow$ David Sappington, "Limited Liability Contracts between Principal and Agent," Journal of Economic Theory, vol. 29 (February 1983), pp. 1-21.

12. If the owners of the firm differ from the managers, then at least the use of debt contracts provides a stronger incentive to the owners to monitor the managers properly. Michael C. Jensen, "Takeovers: Their Causes and Consequences," Journal of Economic Perspectives, vol. 2 (Winter 1988), pp. 21-48, argues that debt reduces the principal-agent problem between owners and managers because it commits the managers to pay out free cash flow that they might otherwise misuse. For an early, formal statement of the free cash flow theory, see Sanford J. Grossman and Oliver D. Hart, "Corporate Financial Structure and Managerial Incentives," in John J. McCall, ed., The Economics of Information and Uncertainty (University of Chicago Press, 1982), pp. 107-37.

13. For a formal development of this point, see Sappington, "Limited Liability Contracts." 
The final rationale for debt, the risk-sharing argument, arises because of market "incompleteness," in the Arrow-Debreu sense. The idea is that it pays firms to issue debt, with its relatively stable payout pattern, in order to be able to borrow at lower cost from risk-averse lenders. This argument is, admittedly, difficult tojustify theoretically; the presumption is that financial intermediaries or individuals would be better placed than an individual firm to repackage risk. Nor is it clear that a bond with a fixed nominal payout stream is the minimum-risk instrument that the firm could offer. Nevertheless, it appears true that, at low levels of debt, the typical firm can raise funds more cheaply through debt than through equity, even neglecting tax advantages. ${ }^{14}$ This advantage to firms of selling debt rather than equity may in part reflect impediments to diversification and insurance that exist in the economy. ${ }^{15}$ Once again the initial net worth of a firm that issues debt is important; the greater the firm's net worth, the safer is the debt that it can issue, and thus the lower the cost of borrowing it will face.

None of these explanations, we should emphasize, helps with what is perhaps the deepest puzzle about debt: the relative lack of indexation of debt returns to easily observable aggregate variables, like the price level, the exchange rate, or even real GNP. All the benefits of debt described above would be increased by indexing to observables. The expected probability of bankruptcy would be lowered (for example, because coupons would be lower in recessions); incentives would be improved; and risk sharing would be facilitated. One almost wants to claim that there is some sort of general preference for simplicity of contracting, but such a claim does not hold up in light of the tremendously complex transactions one sees all the time in modern financial markets.

\section{MICROECONOMIC COSTS OF DEBT}

For a firm whose level of debt has become excessive, because of tax distortions, errors in forecasting firm income, defenses against hostile takeovers, or the like, the microeconomic costs of high debt are the

14. This observation is related to the Mehra-Prescott equity premium puz $\rightarrow$ Rajnish Mehra and Edward C. Prescott, "The Equity Premium: A Puzzie," Journal of Monetary Economics, vol. 15 (March 1985), pp. 145-61.

$\rightarrow$ N. Gregory Mankiw, "The Equity Premium and the Concentration of Aggregate Shocks," Journal of Financial Economics, vol. 17 (September 1986), pp. 211-19. 
mirror image of the benefits of debt issuance, just described. First, the advantage of debt-that it is noncontingent most of the time-is balanced by the real costs that are exacted when the firm cannot repay, the risk of which rises when debt is high relative to the firm's financial resources and income. Bankruptcy costs are usually characterized as tiny relative to firm assets. Direct costs like administrative and legal fees probably are small. ${ }^{16}$ Indirect costs, however, such as the losses due to shutdowns or reorganizations and the destruction of intangible assets, may be more significant.

One argument that bankruptcy costs are actually small is that such costs can almost always in principle be avoided, either by renegotiation of debt terms or by acquisition of the firm by some third party, and yet firms are still allowed to fail. We do not find the argument compelling. Renegotiation of debts can be blocked by "free rider" problems among creditors or by the need of creditors to maintain a reputation for toughness. ${ }^{17}$ Borrowers must not be allowed to expect that they will be allowed to renegotiate. The purchase of the firm by a third party destroys what may be, in some contingencies, an important asset of the firm, namely, its limited liability. A third-party purchaser may also not be able to capture all the social benefits of avoiding bankruptcy; some benefits will go to workers, suppliers, and customers.

Beyond bankruptcy costs, however, are near-bankruptcy costs. Perhaps most important, the theory suggests that a firm near bankruptcy, with its low net worth relative to obligations, will be unable to issue new noncontingent claims, except possibly at high cost. Thus it may be unable to borrow to take advantage of productive opportunities, or even to finance its accounts receivable and its shipments from suppliers. More broadly, the firm will find it difficult to convince anyone, including potential workers, managers, suppliers, and customers, to enter into prospectively long-term relationships with it; this difficulty reduces its ability to operate profitably. An interesting recent study of the TexacoPennzoil dispute by David Cutler and Lawrence Summers noted that the reductions in Texaco's stock market value after adverse court decisions greatly exceeded the corresponding increase in Pennzoil's

16. Jerold B. Warner, "Bankruptcy Costs: Some Evidence," Journal of Finance, vol. 32 (May 1977), pp. 337-47, is always cited on this issue.

$\rightarrow$ Jeremy I. Bulow and John B. Shoven, "The Bankruptcy Decision,' Bell Journal of Economics, vol. 9 (Autumn 1978), pp. 437-56. 
value. The reason, presumably, is that financial distress has negative implications for Texaco's profitability over and beyond the money paid out in settlement. ${ }^{18}$

In a similar way, the good incentive effects of debt when bankruptcy risk is low are balanced by possibly bad incentive effects when bankruptcy risk is high. This theme is a familiar one in the literature and does not have to be developed here. A point perhaps worth making, though, is that the way financial distress distorts decisions may depend on how close to bankruptcy the firm is. The managers of a firm that is doing poorly but is not in immediate danger may become conservative-not introducing new products or modernizing, for example-to avoid potentially fatal mistakes. (We are assuming that managers are not interested just in maximizing firm value per se, but in avoiding bankruptcy. The desire to avoid bankruptcy is reasonable if, for example, managers have job-specific human capital that vanishes if the firm shuts down.) Once bankruptcy becomes likely, on the other hand, gambling becomes a better strategy for the managers. Again, since investors know that managers of near-bankrupt firms may have bad incentives, they will be less willing to supply new funds to the firm in trouble.

Finally we come to the risk-packaging aspect of debt. We have argued that because of barriers to diversification and insurance in the economy, firms that are able to issue safe (noncontingent) securities can obtain a lower cost of capital. Conversely, debt issued by a firm with low financial reserves will be inherently riskier (the firm cannot guarantee repayment in many circumstances), and thus will require a higher return. This reinforces once again a basic theme, that the inability to obtain new funds on reasonable terms is a major cost to the individual firm of having excessive debt outstanding.

MACROECONOMIC IMPLICATIONS OF HIGH LEVELS OF DEBT

Applied economists have long thought that the financial condition of firms plays a role in the persistence and even the initiation of business

18. David M. Cutler and Lawrence H. Summers, "The Costs of Conflict Resolution and Financial Distress: Evidence from the Texaco-Pennzoil Litigation," Working Paper 2418 (National Bureau of Economic Research, October 1987). 
cycles. ${ }^{19}$ A recent theoretical literature, building on advances in the economics of asymmetric information, has tried to formalize this view. ${ }^{20}$ The critical element of these theories is the interaction between firms' net worths and the deadweight losses arising from asymmetric information. The basic idea is simple. Suppose a negative shock, perhaps a productivity shock, initiates a recession and reduces the net worth of firms. Because net worth is lower, firms find it more costly and difficult to raise external funds. Both their supply of goods and their demands for new capital fall, tending to worsen the recession.

High levels of debt tend to magnify the sensitivity of firm net worth or equity values to aggregate shocks. For example, in a highly levered firm the percentage decline in net worth after an adverse shock may be much greater than the decline in the value of the firm as a whole. Another example, recently stressed by Bernanke and Gertler, is "debt-deflation." 21 In a debt-deflation, an unanticipated fall in the general price level or a slower than expected inflation redistributes wealth from firms to creditors; the effect is not macroeconomically neutral, because lower firm net worth has negative effects on investment and output.

The policy implications of these models are not completely clear. Although economic fluctuations in the Bernanke-Gertler model are not first-best (because of the asymmetric information), neither are there any well-defined externalities that would imply a useful role for government intervention. Bernanke and Gertler do suggest a limited policy of debt relief, in the form of transfers from creditors to debtors, after a debtdeflation; but, as they emphasize, this policy is not Pareto-improving, even though it increases output and some measures of total welfare.

To justify public intervention in firms' debt decisions, there must be additional imperfections in the economy giving rise to some sort of aggregate externality. Probably Keynesian wage or price stickiness

19. Otto Eckstein and Allen Sinai, "The Mechanisms of the Business Cycle in the Postwar Era," in Robert J. Gordon, ed., The American Business Cycle: Continuity and Change (University of Chicago Press, 1986), pp. 39-105.

20. Stephen D. Williamson, "Financial Intermediation, Business Failures, and Real Business Cycles," Journal of Political Economy, vol. 95 (December 1987), pp. 1196-1216; Bruce Greenwald and Joseph Stiglitz, "Information, Finance Constraints and Business Fluctuations" (Princeton University, June 1986); Ben Bernanke and Mark Gertler, "Agency Costs, Net Worth, and Business Fluctuations" (Princeton University, December 1987).

21. The term is due to Irving Fisher. Ben Bernanke and Mark Gertler, "Financial Fragility and Economic Performance," Working Paper 2318 (NBER, July 1987). 
would do it, since in this case firms' spending decisions have spillover effects on the aggregate level of output and welfare. ${ }^{22}$ An alternative suggestion put forth by Keynesians is that the economy has multiple equilibria, and that the economy's "choice" of equilibrium may be history-dependent, leading to hysteresis in the macroeconomy. ${ }^{23}$ Widespread financial distress, through its effect on confidence, could conceivably induce a movement to a lower equilibrium; one could at least argue that such was the case during the Depression. The existence of increasing returns is also a potential form of aggregate externality.$^{24}$ In each of these cases, high levels of debt may act as an automatic destabilizer, increasing the sensitivity of spending to exogenous shocks. Concern about the level of debt would be in this case well justified.

An alternative, and even more informal, explanation also relies on the possible existence of multiple equilibria. The idea is that a succession of bankruptcies, made more likely by a high level of debt, might lead to a generalized liquidity crisis. Something of this sort appears to have occurred during the early 1930s, although at that time it involved banks more than nonfinancial firms; some people think it nearly happened again during the Penn Central episode in 1970.25 The argument here is predicated on the view that firms perform a liquidity-transformation function analogous to the one performed by banks. ${ }^{26}$ Thus the firm's assets may be more illiquid than are its liabilities. Like the bank that counts on only a fraction of its depositors needing to withdraw cash at any given time, the firm whose assets are relatively illiquid compared with its liabilities must count on being able to roll over much of its debt as it comes due. Confidence is obviously crucial in such a situation. As

22. John Caskey and Steven Fazzari, "Price Flexibility and Macroeconomic Stability: An Empirical Simulation Analysis" (Washington University, December 1987), work out a sticky-price model of this sort.

23. Lawrence H. Summers, "Should Keynesian Economics Dispense with the Phillips Curve?" in Rod Cross, ed., Unemployment, Hysteresis, and the Natural Rate Hypothesis (Basil Blackwell, 1988), pp. 11-25.

24. Andrei Shleifer, "Implementation Cycles," Journal of Political Economy, vol. 94 (December 1986), pp. 1163-90.

25. See the description in Marcia Stigum, The Money Market (Dow Jones-Irwin, 1983). See also "Liquidity and Credit in the Second Quarter," Federal Reserve Bank of New York Monthly Review, vol. 52 (August 1970), pp. 182-86.

26. For a formal analysis, see Douglas W. Diamond and Philip H. Dybvig, "Bank Runs, Deposit Insurance and Liquidity," Journal of Political Economy, vol. 91 (June 1983), pp. 401-19. 
Diamond and Dybvig show for the case of a liquidity-creating bank, there are two classes of equilibria- "good" equilibria in which confident depositors withdraw only when genuinely in need of liquidity and "bad" equilibria in which the fear that the bank cannot honor its commitments becomes self-confirming, as depositors run on the bank.

Although firms do not issue demand deposits, something like a run is conceivable if all short-term creditors try to get out simultaneously; the firm would then have difficulty refinancing its debt. Bankruptcies or financial distress among some major firms could contribute to a general liquidity crisis in several ways. Perhaps most important would be the effect of such news on the fragile confidence that supports the first Diamond-Dybvig equilibrium. More directly, the legal proceedings initiated by bankruptcy would freeze the liabilities of the failing firms, converting assets that the firms' creditors may have previously considered to be fairly liquid into illiquid assets and worsening the illiquidity problem of the creditors. Similarly, major bankruptcies might contribute to cash-flow problems of the firms' suppliers and customers. As the liquidity crisis of the 1930s seriously disrupted the ability of banks to function, a corporate liquidity crisis could disrupt the production and investment activities of firms. In such a situation, the liquidity of nonfinancial firms and of banks would be closely intertwined, because, for example, most firms back their commercial paper issuance with bank lines of credit, which would provide relief in a crisis only if the banks remained liquid. ${ }^{27}$

This particular scenario is speculative. As noted, the liquidity crisis of the Depression was focused primarily on financial institutions; major corporations entered the 1930s with large cash cushions and remained relatively liquid throughout the decade. Thus we do not have a clear example of a corporate liquidity crisis to which to point; we raise this only as a possibility. The macroeconomic implications of financial structure remain a rich field for theorists. Based on what we know now, however, there does seem to be reason for macroeconomists to pay attention to the mixture of corporate debt and equity in the economy. We turn next to some empirical measures of the importance of debt in the U.S. economy.

27. Stigum, The Money Market, pp. 632-35. 


\section{Measures of Corporate Financial Stability}

We first look at the extent to which the recent growth of corporate debt has affected basic measures of corporate financial stability based on aggregate averages. Because what is important is not debt itself, but debt relative to the value of the firm, we focus on debt-to-asset ratios as our basic indicators of financial conditions.

Six measures of aggregate debt-asset ratios for U.S. corporations during 1969-86 are given in table 3, which is, except for the last two columns, essentially an update of similar tables reported by Robert Taggart. ${ }^{28}$ The six columns of table 3 tell a reasonably consistent story. Aggregate debt-asset ratios have been either flat or mildly upward sloping. The two measures that include a market value of equity (columns 1 and 4) show a large increase in the debt-asset ratio in 1974, a year in which the stock market fell sharply. Some of the 1974 increase appears to have been permanent. There is no evidence in this table that debtasset ratios in the 1980s have been high relative to the post-oil shock 1970s. ${ }^{29}$

The measures in table 3 present several problems, however. First, only the Holland-Myers approach (column 4) uses a market value of debt, and it is rather crude. ${ }^{30}$ But given the volatility of inflation over the sample period, it is likely that market values have fluctuated much more than book values. Further, it is the market value of debt that is economically significant, since presumably firms can always refinance existing debt at current interest rates, thereby effectively redeeming their outstanding debt at market value.

Second, the aggregate debt-asset ratios in table 3 may conceal important variations in the cross-sectional distribution of this variable. Because a primary concern in evaluating the risk of a financial crisis is

28. Taggart, "Secular Patterns in the Financing of U.S. Corporations."

29. As we have already noted, Taggart's work shows that debt-asset ratios were generally lower in the 1950 s and 1960s than in our sample period, but in a long historical perspective those two decades appear to be exceptional.

30. In general the market value of long-term corporate debt depends on the pattern of interest rates over previous years, a principle that is ignored when capitalization is done using only the current long-term rate. 
Table 3. Alternative Aggregate Debt-Asset Ratios, 1969-86

\begin{tabular}{|c|c|c|c|c|c|c|}
\hline \multirow[b]{2}{*}{ Year } & \multirow[b]{2}{*}{$\begin{array}{l}\text { Flow-of- } \\
\text { Funds }\end{array}$} & \multicolumn{2}{|c|}{ Internal Revenue Service } & \multirow{2}{*}{$\begin{array}{c}\text { Holland } \\
\text { and } \\
\text { Myers }\end{array}$} & \multicolumn{2}{|c|}{ COMPUSTAT } \\
\hline & & $\begin{array}{c}\text { All } \\
\text { corporations }\end{array}$ & $\begin{array}{c}\text { Manufacturing } \\
\text { corporations }\end{array}$ & & $\begin{array}{l}\text { Fixed } \\
\text { sample }\end{array}$ & $\begin{array}{l}\text { Growing } \\
\text { sample }\end{array}$ \\
\hline 1969 & 0.34 & 0.70 & 0.45 & 0.22 & 0.31 & 0.31 \\
\hline 1970 & 0.35 & 0.71 & 0.49 & 0.28 & 0.32 & 0.31 \\
\hline 1971 & 0.33 & 0.72 & 0.49 & 0.26 & 0.32 & 0.30 \\
\hline 1972 & 0.33 & 0.72 & 0.49 & 0.25 & 0.31 & 0.30 \\
\hline 1973 & 0.35 & 0.73 & 0.51 & 0.29 & 0.30 & 0.28 \\
\hline 1974 & 0.51 & 0.74 & 0.53 & 0.39 & 0.30 & 0.29 \\
\hline 1975 & 0.44 & 0.74 & 0.52 & 0.31 & 0.29 & 0.31 \\
\hline 1976 & 0.43 & 0.74 & 0.53 & 0.27 & 0.28 & 0.29 \\
\hline 1977 & 0.47 & 0.74 & 0.53 & 0.33 & 0.27 & 0.28 \\
\hline 1978 & 0.49 & 0.75 & 0.54 & 0.35 & 0.26 & 0.27 \\
\hline 1979 & 0.47 & 0.74 & 0.55 & 0.35 & 0.25 & 0.27 \\
\hline 1980 & 0.41 & 0.74 & 0.56 & 0.32 & 0.25 & 0.27 \\
\hline 1981 & 0.45 & 0.74 & 0.53 & 0.29 & 0.26 & 0.27 \\
\hline 1982 & 0.44 & 0.74 & 0.57 & 0.31 & 0.27 & 0.27 \\
\hline 1983 & 0.41 & 0.74 & 0.57 & 0.25 & 0.25 & 0.25 \\
\hline 1984 & 0.45 & 0.74 & 0.58 & 0.27 & 0.26 & 0.26 \\
\hline 1985 & 0.43 & n.a. & n.a. & 0.29 & 0.27 & 0.26 \\
\hline 1986 & 0.42 & n.a. & n.a. & 0.30 & 0.28 & 0.27 \\
\hline
\end{tabular}

Sources: Column 1 is total credit market instruments of nonfinancial corporations measured at book value, divided by the sum of credit market instruments and the market value of equity, as reported in Board of Governors of the Federal Reserve System, "Balance Sheets for the U.S. Economy, 1946-85" and "Flow of Funds Accounts," various issues. Columns 2 and 3 are total debt divided by total assets (all at book value), as reported in U.S. Internal Revenue Service, Statistics of Income, various issues. Column 4, using the approach of Holland and Myers, is the ratio of the market value of nonfinancial corporate debt to the sum of the market values of nonfinancial corporate debt and equity; the aggregate market values of corporate debt and equity are measured as the capitalized values of nonfinancial corporate net interest and dividends (from the National Income and Product Accounts), where capitalization rates are the Baa corporate bond rate and the Standard and Poor's 500 dividend yield, respectively. See Daniel M. Holland and Stewart C. Myers, "Trends in Corporate Profitability and Capital Costs" in Robert Lindsay, ed., The Nation's Capital Needs: Three Studies (New York: Committee for Economic Development, 1979), pp. 103-88. The last two columns of the table use a fixed sample (column 5) of 643 COMPUSTAT firms (the firms for which all relevant data are available continuously over 1969-86) and a growing sample (column 6) of COMPUSTAT firms (including in each year all firms for which data are available in that year). The numbers reported in columns 5 and 6 are the ratios of book-value debt to book-value assets.

n.a. Not available.

the number of firms that would be in financial distress in the event of a major shock, the upper tail of the debt-asset distribution is of greater interest than the mean or median value.

To get at the issue of the size of the tail, one needs panel data on firm balance sheets; although not essential, such panel data are also helpful for calculating market values of debt, since they can be used to infer the maturity structure of outstanding debt. For this study we focus our attention on the COMPUSTAT data set. We had available the primary, 
supplementary, and tertiary COMPUSTAT files; after eliminating financial corporations (SIC 6) and firms with essential missing data, we had a sample that started with some 700 firms in 1969 and grew to some 1,400 firms by 1986 . About 650 firms had data available consistently throughout the sample period; we dubbed this our fixed sample, as opposed to the growing sample, which includes firms added to the COMPUSTAT data base over time.

COMPUSTAT's advantages are its familiarity and completeness. Its primary disadvantage is that the firms for which it provides data, being both publicly traded and larger than typical firms, may not be representative of U.S. nonfinancial corporations as a whole. In table 2, for example, the dividend payments of the 643 firms in our fixed sample amount to almost half the total dividend payments of the nonfinancial corporate sector in 1986, but the debt issue of these firms is only about one-fifth the total for the sector. The ratio of dividends to debt issue is similarly disproportionate for our growing sample of firms. The reason presumably is the high weight in our sample of large, mature firms that pay larger dividends and issue less debt, relative to their size, than smaller firms.

The COMPUSTAT data set also includes only firms that were viable and publicly traded at the end of the sample period. Firms that failed or went private during the period are excluded throughout. This "survivorship bias" could lead us to understate increases in debt-asset ratios, if leverage has increased primarily in firms that have gone private. ${ }^{31} \mathrm{On}$ the other hand, firms whose financial conditions deteriorated early in the sample, and that subsequently failed, are excluded while firms with deteriorating conditions in the past few years remain in the sample. This bias works to overstate increases in debt-asset ratios, although its effect is very likely smaller than the understatement arising from omitted private firms. Despite these caveats about our COMPUSTAT sample, we note that the results we obtain are qualitatively similar to those for the corporate sector as a whole, reported in table 3, column 1.

Our first major undertaking was to construct market debt-asset ratios

31. Michael Jensen, "Takeovers: Causes and Consequences," reports that the total market value of firms that went private was $\$ 37.4$ billion in 1985 and $\$ 44.3$ billion in 1986 . The ultimate source of this information is Mergerstat Review (W. T. Grimm and Co., 1985 and 1986 annual issues). Substantial debt issue was associated with many of these corporate restructurings. 
for each firm in each year. Because market equity values are available, the main problem was to assign market values for outstanding debt. ${ }^{32}$ We used a variety of different methods, which we briefly describe in the next section.

\section{CALCULATING MARKET VALUES OF DEBT}

We began by ignoring special features that exist on some corporate debt issues, such as call provisions. ${ }^{33}$ Then the market value of a debt issue can be calculated from its book value, maturity, coupon rate, and yield to maturity, using the standard present-value formulas. The market value of a firm's debt is simply the sum of the values of individual issues of different maturities.

The COMPUSTAT tape has only minimal direct information on the variables that enter the present-value formula for debt. The tape does report the total book value of short-term debt (under one-year maturity at issue) and long-term debt (over one-year maturity at issue), and also the book-value maturity distribution of outstanding long-term debt out to five years. ${ }^{34}$

The procedure introduced by William Brainard, John Shoven, and Laurence Weiss (BSW), and subsequently applied by others, uses the total short- and long-term debt numbers and imputes the maturity distribution of long-term debt. ${ }^{35}$ Each firm is followed through time; at the starting date, it is assumed that the maturity distribution of the firm's long-term debt is equal to the aggregate average for that date. The

32. Actually, only common stock values are directly available. We calculated preferred stock values by capitalizing each firm's preferred dividend payments by the aggregate preferred dividend yield.

33. Ben Friedman suggested to us that ignoring call provisions may be an important omission during the $1980 \mathrm{~s}$, when interest rates fell sharply. In this case, reported book values may be better measures of market value than our constructed numbers. Column 1 of table 3 reports the ratio of book value of debt to market value of equity for the corporate sector as a whole. The behavior of this series is qualitatively similar to that of our marketvalue series. At no time in the 1980s has this ratio been as high as it was in 1974 or 1977-79.

34. That is, the tape reports the book value of long-term debt due in under one year, due in one to two years, and so on out to five years. These numbers are available starting in 1974 for some firms.

35. William C. Brainard, John B. Shoven, and Laurence Weiss, "The Financial Valuation of the Return to Capital," BPEA, 2:1980, pp. 453-502. We are grateful to John Shoven for supplying us with a FORTRAN program to carry out the BSW method. 
maturity distribution is updated each year, assuming that net new issues have a 20-year maturity and that net retirements apply to all outstanding issues proportionately. The net issue number is obtained as the change in total book value of long-term debt, adjusted for maturing issues. Once the maturity distribution of long-term debt is obtained, the BSW procedure assumes that each issue has a coupon rate equal to the Baa rate at the time of issue, and a yield to maturity equal to the current Baa rate. ${ }^{36}$

The BSW method does not use the information directly available from COMPUSTAT on the maturity distribution of long-term debt out to five years' maturity. A simple modification of the approach is to replace the first five years of the BSW maturity distribution with the COMPUSTAT numbers, scaling the remainder of the BSW distribution up or down in proportion to remain consistent with the COMPUSTAT figure on total long-term debt. ${ }^{37}$ The modified distribution is then carried forward to the next year and updated in the manner of BSW.

We calculated market values of debt using both the plain and the modified BSW method for both our fixed and growing samples of firms, assuming that the maturity of long-term corporate debt at issue is either 10 or 20 years. These eight alternative calculations yielded similar results; in the next section, therefore, we report the results using the modified BSW method with a growing sample and a 20 -year debt maturity at issue.

The BSW approach does not use information on net interest paid by the firm, which is available. Ideally, the interest numbers should be incorporated into the BSW calculation, and we made several attempts to do so. But while on average the ratios of interest to book value of debt reported by COMPUSTAT look reasonable, for a substantial minority of firms reported interest expense and book values of debt appear to be inconsistent, in that there is no possible maturity structure for which the implied average coupon rate is reasonable. Rather than simply ignore the information on interest paid, which may be more accurate than the debt numbers, we used it as the basis of a separate calculation. ${ }^{38}$

36. A fixed-maturity (approximately 10-year) Baa rate is used.

37. One way to justify this is to imagine that the firm refinances its debt each year to adjust the maturity distribution.

38. For an independent confirmation of the accuracy of the basic BSW method that uses book value of debt data, see John H. Ciccolo, Jr., "Changing Balance Sheet Relationships in the U.S. Manufacturing Sector," in Benjamin M. Friedman, ed., The Changing Roles of Debt and Equity in Financing U.S. Capital Formation (University of Chicago Press, 1982), pp. 65-74. 
We began by computing the interest payments implied by the BSW method. Then we scaled up the BSW market value of debt by the ratio of reported to implied interest. One can think of this as using the BSW maturity structure, plus historical coupon rates, to allocate reported interest to obligations at different maturities. Below we present marketvalue debt-asset ratios computed in this way, as an alternative to the more usual methods.

\section{DISTRIBUTION OF DEBT-ASSET RATIOS}

We now present distributions of market-value debt-asset ratios over time for each of two imputation methods. Method A is the BrainardShoven-Weiss approach, modified to reflect additional sample information, when available, about the maturity structures of firms' debt. We assume that long-term debt is issued at a 20-year maturity. In Method B the market value of debt is measured by capitalizing reported interest payments, using the debt maturity structure and coupon rates implied in each year by Method A.

Both methods use the growing sample of firms (the fixed-sample results were very similar). In table 4 we report results for the full sample (that is, the total market value of debt divided by the total market value of assets, or equivalently the value-weighted mean debt-asset ratio for the sample). In table 5 we report the $50 \mathrm{th}, 90 \mathrm{th}, 95 \mathrm{th}$, and 99 th percentiles of the debt-asset distribution. ${ }^{39}$

The results obtained by Methods $\mathrm{A}$ and $\mathrm{B}$ are reassuringly similar; both are quite different from the book-value methods. Because a variety of permutations of the market-value calculation not reported in the table also gave similar results, we feel relatively confident about the conversion of debt numbers to market values.

39. The percentiles in table 5 are calculated on an equal-weighted basis, but we also computed value-weighted percentiles. In the equal-weighted calculation, a firm at the 95 th percentile has a higher debt-asset ratio than 95 percent of all the firms in the sample in that year. In the value-weighted calculation, the firms with debt-asset ratios lower than the 95th percentile firm have an aggregate market asset value equal to 95 percent of the total value of firms in that year. If debt-asset ratios are larger for smaller firms, then the debtasset ratios at a given point in the right-hand tail should be higher under the equal-weighted method than under the value-weighted method. We found this to be the case empirically, but the movements over time in the value-weighted percentiles were almost identical to those in the equal-weighted percentiles. 
Table 4. Book-Value and Market-Value Debt-Asset Ratios, COMPUSTAT Firms, 1969-86

\begin{tabular}{lcccc}
\hline & & \multicolumn{2}{c}{ Market value $^{\mathrm{a}}$} & $\begin{array}{c}\text { Number of } \\
\text { Yirms in } \\
\text { Year }\end{array}$ \\
\cline { 2 - 4 } & $\begin{array}{c}\text { Book- } \\
\text { value }\end{array}$ & $\begin{array}{c}\text { Method } \\
A^{\mathrm{b}}\end{array}$ & $\begin{array}{c}\text { Method } \\
B^{\mathrm{c}}\end{array}$ & 643 \\
\hline 1969 & 0.300 & 0.260 & 0.254 & 695 \\
1970 & 0.290 & 0.257 & 0.247 & 747 \\
1971 & 0.281 & 0.247 & 0.234 & 800 \\
1972 & 0.268 & 0.235 & 0.219 & 859 \\
1973 & 0.257 & 0.270 & 0.267 & 902 \\
1974 & 0.283 & 0.368 & 0.388 & 932 \\
1975 & 0.287 & 0.325 & 0.334 & 966 \\
1976 & 0.272 & 0.303 & 0.308 & 1,013 \\
1977 & 0.273 & 0.345 & 0.354 & 1,051 \\
1978 & 0.266 & 0.350 & 0.365 & 1,085 \\
1979 & 0.264 & 0.336 & 0.351 & 1,122 \\
1980 & 0.251 & 0.286 & 0.308 & 1,169 \\
1981 & 0.263 & 0.317 & 0.344 & 1,197 \\
1982 & 0.257 & 0.308 & 0.330 & 1,259 \\
1983 & 0.241 & 0.286 & 0.303 & 1,321 \\
1984 & 0.248 & 0.304 & 0.309 & 1,386 \\
1985 & 0.256 & 0.298 & 0.288 & 1,386 \\
1986 & 0.273 & 0.311 & 0.298 &
\end{tabular}

Sources: Authors' calculations using the COMPUSTAT data base.

a. The numbers are the ratios of the total market value of debt for the sample to the total market value of assets. Equivalently, they are the value-weighted mean debt-asset ratios for the sample.

b. Brainard-Shoven-Weiss approach, modified to reflect additional sample information (when available) about the maturity structures of firms' debt. Long-term debt is assumed to be issued at a 20 -year maturity. See text description and William C. Brainard, John B. Shoven, and Laurence Weiss, "The Financial Valuation of the Return to Capital," BPEA, 2:1980, pp. 453-502.

c. The market value of debt is measured by capitalizing reported interest payments, using the debt maturity structure and coupon rates implied in each year by Method A.

The market debt-asset ratios at all points of the cross-sectional distribution of firms show the same recent historical pattern. There was a corporate debt crisis in 1974, in the sense that debt-asset ratios rose sharply. Debt-asset ratios fell slowly after 1974 until perhaps about 1980. There has been no significant trend in this measure during the $1980 \mathrm{~s}$ because the recent growth of total debt has been offset by the rising stock market. Whether the stock market crash of 1987 affects this conclusion is discussed later. Our calculation, which always uses the Baa bond rate, ignores the possibility that there have been net downgradings recently; if downgradings have been important, then our numbers overstate the market value of debt in recent years. 


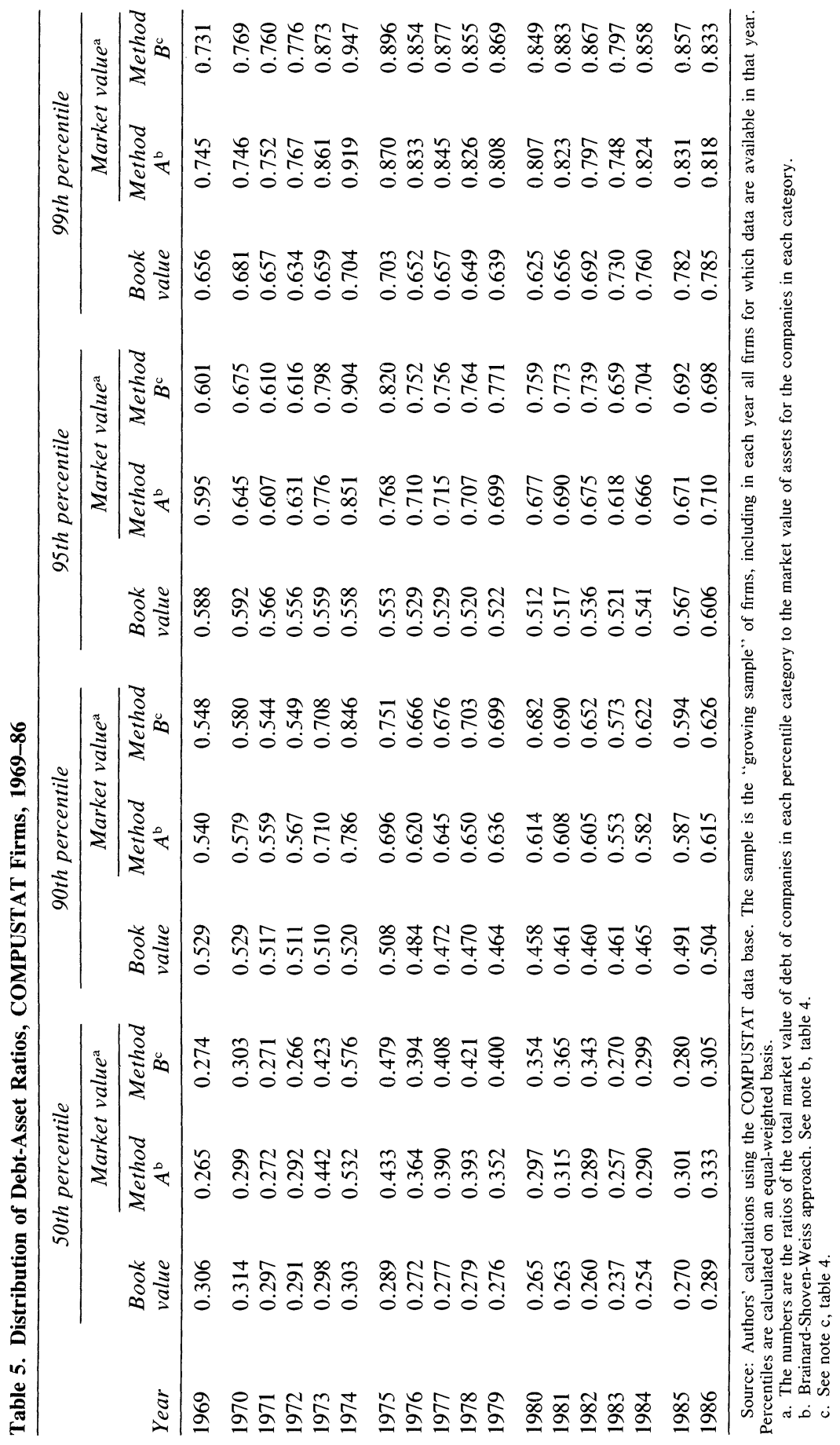


The ratio of the market value of debt to the market value of assets seems to us to be the best single indicator of the solvency of the corporate sector. Nevertheless, numerous other measures of liquidity and solvency, used for example by professional bond raters, do not rely on stock market values. ${ }^{40}$ There are several good reasons to consider these as well. First, the stock market may not be a reliable measure of fundamental valuation. Second, from a policy perspective, we should be interested in worst-case scenarios as well as the average expected outcome reflected in even correctly priced equities.

A popular flow measure of financial soundness is the ratio of interest paid by the firm to cash flow before depreciation, taxes, and interest. Obviously a liquidity rather than a solvency measure, this ratio describes the pressure exerted by interest payments on current cash flows. Table 6 gives the equal-weighted distribution of this measure. Table 7 reports a similar measure that distinguishes between nominal and real interest; here the numerator is a crude measure of real interest paid by the firm, rather than nominal interest. Table 8 gives the distribution for the basic measure, with current cash flow replaced by an average of cash flow over the current and the two previous years.

Because of high real interest rates in the 1980s and the legacy of high nominal interest rates during the 1970s, and because the firms in our sample had relatively poor average earnings during the 1980s, both absolutely and relative to national averages, all measures of interest expense have risen significantly recently. The increase is particularly striking for the real interest expense statistic (table 7). Even at the median, the current burden of real interest payments has approximately quadrupled since the late 1970s. This pressure on cash flows may be the proximate reason for the increased number of bond downgradings noted by Kaufman and others.

40. Harlan D. Platt, Why Companies Fail: Strategies for Detecting, Avoiding, and Profiting from Bankruptcy (Lexington Books, 1985), chap. 8, discusses the use of flow measures for predicting bankruptcy and reviews earlier statistical studies. There seems to have been little structural modeling of the determinants of bankruptcy; the forecasting equations that are used are "best-fit" reduced forms. See also Edward I. Altman, Corporate Bankruptcy in America (Lexington Books, 1971). 
Table 6. Interest Expense as a Ratio to Cash Flow, COMPUSTAT Firms, 1969-86 a

\begin{tabular}{lccccc}
\hline & & \multicolumn{3}{c}{ Percentile } & $\begin{array}{c}\text { Number of } \\
\text { firms in } \\
\text { Yeample }\end{array}$ \\
\cline { 2 - 5 } & sample & 50 & 90 & 95 & 643 \\
1969 & 0.12 & 0.13 & 0.34 & 0.44 & 695 \\
1970 & 0.14 & 0.16 & 0.46 & 1.07 & 747 \\
1971 & 0.13 & 0.16 & 0.44 & 0.89 & 800 \\
1972 & 0.12 & 0.14 & 0.37 & 0.50 & 859 \\
1973 & 0.12 & 0.14 & 0.38 & 0.50 & 902 \\
1974 & 0.13 & 0.18 & 0.53 & 0.90 & 932 \\
1975 & 0.15 & 0.19 & 0.47 & 0.76 & 966 \\
1976 & 0.14 & 0.14 & 0.38 & 0.53 & 1,013 \\
1977 & 0.14 & 0.15 & 0.41 & 0.62 & 1,051 \\
1978 & 0.14 & 0.15 & 0.41 & 0.57 & 1,085 \\
1979 & 0.14 & 0.17 & 0.47 & 0.66 & 1,122 \\
1980 & 0.18 & 0.20 & 0.56 & 0.95 & 1,169 \\
1981 & 0.21 & 0.22 & 0.66 & 1.28 & 1,197 \\
1982 & 0.22 & 0.24 & 1.18 & $\infty$ & 1,259 \\
1983 & 0.18 & 0.20 & 0.99 & $\infty$ & 1,321 \\
1984 & 0.18 & 0.19 & 0.81 & $\infty$ & 1,386 \\
1985 & 0.18 & 0.21 & 1.67 & $\infty$ & 1,386 \\
1986 & 0.20 & 0.22 & 1.65 & $\infty$ &
\end{tabular}

Source: Same as table 5 .

a. This table shows the ratio of interest expense to operating income before depreciation, taxes, and interest expense. Negative values and values greater than 100 are shown as $+\infty$. A column for the 99 th percentile is omitted as almost all values are $+\infty$.

Instead of measuring interest costs relative to the current cash flow, table 9 measures interest relative to current assets. Current assets, defined as the sum of cash and equivalents, receivables, inventories, and some miscellaneous items, may be a better indicator of a firm's ability to meet its interest obligations than is income, particularly if current income has a large transitory component. This ratio does deteriorate over our sample period but less dramatically than does the interest-to-cash-flow ratio; it tends gradually upward with something of a break around 1980 .

Another variable of interest is the proportion of debt at market value that is due within the year. A high ratio of debt due in the near term would signify pressure on firms either to find refinancing or to repay principal out of current earnings. As table 10 shows, however, there is virtually no trend in this ratio. 
Table 7. Real Interest Expense as a Ratio to Cash Flow, COMPUSTAT Firms, 1969-86 ${ }^{\text {a }}$

\begin{tabular}{cccccc}
\hline & & \multicolumn{3}{c}{ Percentile } & $\begin{array}{c}\text { Number of } \\
\text { Yirms in } \\
\text { Year }\end{array}$ \\
\cline { 2 - 5 } $\begin{array}{c}\text { Fample } \\
\text { sample }\end{array}$ \\
\hline 1969 & 0.00 & 0.00 & 0.01 & 0.02 & 643 \\
1970 & 0.06 & 0.06 & 0.18 & 0.42 & 695 \\
1971 & 0.04 & 0.05 & 0.15 & 0.29 & 747 \\
1972 & 0.05 & 0.06 & 0.15 & 0.21 & 800 \\
1973 & 0.03 & 0.03 & 0.08 & 0.11 & 859 \\
1974 & 0.01 & 0.01 & 0.02 & 0.04 & 902 \\
1975 & 0.01 & 0.01 & 0.04 & 0.06 & 932 \\
1976 & 0.05 & 0.05 & 0.13 & 0.18 & 966 \\
1977 & 0.04 & 0.04 & 0.11 & 0.16 & 1,013 \\
1978 & 0.03 & 0.04 & 0.09 & 0.13 & 1,051 \\
1979 & 0.02 & 0.03 & 0.08 & 0.11 & 1,085 \\
1980 & 0.06 & 0.07 & 0.19 & 0.32 & 1,122 \\
1981 & 0.08 & 0.09 & 0.26 & 0.51 & 1,169 \\
1982 & 0.13 & 0.15 & 0.71 & $\infty$ & 1,197 \\
1983 & 0.13 & 0.14 & 0.70 & $\infty$ & 1,259 \\
1984 & 0.13 & 0.14 & 0.60 & 3.15 & 1,321 \\
1985 & 0.14 & 0.16 & 1.24 & $\infty$ & 1,386 \\
1986 & 0.15 & 0.17 & 1.23 & $\infty$ & 1,386 \\
\hline
\end{tabular}

Source: Same as table 5 .

a. The numbers in this table are the numbers in table 6 , multiplied by the ratio of the Baa rate less the ex post inflation rate to the Baa rate. Negative values and values greater than 100 are shown as $+\infty$. A column for the 99 th percentile is omitted as almost all values are $+\infty$.

The variables considered in this section concern liquidity, as opposed to solvency. They give mixed results. The ratios of interest to cash flow and current assets show signs of stress, but there is no increased reliance on short-term debt. In relatively normal times, at least, liquidity is less important than solvency, since a solvent firm will be able to find financing to cover any liquidity problems. As discussed earlier, in a crisis atmosphere liquidity may become more important, in which case our findings carry some possibly worrisome implications.

The conflict between the results in tables 6-9 and the debt-asset measures in tables 4 and 5 reflects stock prices, as is clear from table 11. There has been a remarkable swing in price-earnings ratios in the past two decades, with ratios in the late 1960s and recent years, even after the crash of 1987, being high relative to historical norms and those in the mid-1970s being unusually low. Thus debt growth has been matched by growth in equity values, leaving debt-asset ratios essentially unchanged; 
Table 8. Interest Expense as a Ratio to a Three-Year Moving Average of Cash Flow, COMPUSTAT Firms, 1971-86 ${ }^{\text {a }}$

\begin{tabular}{lccccr}
\hline & & \multicolumn{3}{c}{ Percentile } & $\begin{array}{c}\text { Number of } \\
\text { Yirms in } \\
\text { Yeample }\end{array}$ \\
\cline { 2 - 5 } & Fumple & 50 & 90 & 95 & 747 \\
\hline 1971 & 0.14 & 0.17 & 0.44 & 0.67 & 800 \\
1972 & 0.14 & 0.16 & 0.44 & 0.63 & 859 \\
1973 & 0.14 & 0.18 & 0.48 & 0.73 & 902 \\
1974 & 0.16 & 0.21 & 0.55 & 0.82 & 932 \\
1975 & 0.16 & 0.19 & 0.49 & 0.63 & 966 \\
1976 & 0.15 & 0.17 & 0.42 & 0.58 & 1,013 \\
1977 & 0.15 & 0.17 & 0.44 & 0.64 & 1,051 \\
1978 & 0.16 & 0.18 & 0.47 & 0.69 & 1,085 \\
1979 & 0.16 & 0.20 & 0.53 & 0.73 & 1,122 \\
1980 & 0.19 & 0.21 & 0.57 & 0.85 & 1,169 \\
1981 & 0.22 & 0.24 & 0.68 & 1.11 & 1,197 \\
1982 & 0.23 & 0.24 & 0.74 & 1.32 & 1,259 \\
1983 & 0.21 & 0.21 & 0.77 & 1.33 & 1,321 \\
1984 & 0.20 & 0.23 & 0.97 & 2.01 & 1,386 \\
1985 & 0.19 & 0.23 & 0.98 & 4.43 & 1,386 \\
1986 & 0.20 & 0.23 & 1.02 & 4.70 & \\
\hline
\end{tabular}

Source: Same as table 5 .

a. The numbers are defined as in table 5, with the average of current and two previous years of operating income replacing current operating income. Negative values and values greater than 100 are shown as $+\infty$. A column for the 99 th percentile is omitted as almost all values are $+\infty$.

but debt growth has significantly outstripped earnings growth, leading to increased interest burdens.

\section{CORPORATE FINANCIAL CONDITIONS AND BANKRUPTCY RISK}

The analysis of the previous section helps us measure changes in the financial conditions of firms, but it does not provide direct estimates of increases in bankruptcy risk. A complete analysis of the connection between financial conditions and bankruptcy risk is beyond the scope of the paper, but we do try two empirical exercises that shed some light on the issue. First, we study the experience of a large firm that came close to bankruptcy in the middle of our sample period; and second, we look at trends in a reduced-form measure that is commonly used by business economists as an indicator of bankruptcy risk.

The Chrysler Episode. In table 12 we report stock and flow measures of the financial condition of Chrysler Corporation over our sample period. During the late 1970s, Chrysler faced serious difficulties that 
Table 9. Ratio of Interest Expense to Current Assets, COMPUSTAT Firms, 1969-86a

\begin{tabular}{|c|c|c|c|c|c|c|}
\hline \multirow[b]{2}{*}{ Year } & \multirow{2}{*}{$\begin{array}{c}\text { Full } \\
\text { sample }\end{array}$} & \multicolumn{4}{|c|}{ Percentile } & \multirow{2}{*}{$\begin{array}{l}\text { Number of } \\
\text { firms in } \\
\text { sample }\end{array}$} \\
\hline & & 50 & 90 & 95 & 99 & \\
\hline 1969 & 0.04 & 0.04 & 0.23 & 0.34 & 0.59 & 643 \\
\hline 1970 & 0.05 & 0.04 & 0.25 & 0.40 & 0.62 & 694 \\
\hline 1971 & 0.05 & 0.04 & 0.24 & 0.38 & 0.62 & 746 \\
\hline 1972 & 0.05 & 0.04 & 0.23 & 0.37 & 0.59 & 799 \\
\hline 1973 & 0.05 & 0.04 & 0.24 & 0.39 & 0.64 & 857 \\
\hline 1974 & 0.06 & 0.05 & 0.27 & 0.37 & 0.58 & 900 \\
\hline 1975 & 0.07 & 0.05 & 0.25 & 0.40 & 0.60 & 929 \\
\hline 1976 & 0.06 & 0.04 & 0.24 & 0.36 & 0.55 & 962 \\
\hline 1977 & 0.06 & 0.04 & 0.22 & 0.34 & 0.54 & 1,006 \\
\hline 1978 & 0.06 & 0.05 & 0.22 & 0.36 & 0.57 & 1,044 \\
\hline 1979 & 0.06 & 0.05 & 0.22 & 0.38 & 0.59 & 1,078 \\
\hline 1980 & 0.07 & 0.06 & 0.23 & 0.39 & 0.65 & 1,117 \\
\hline 1981 & 0.09 & 0.06 & 0.26 & 0.42 & 0.70 & 1,162 \\
\hline 1982 & 0.10 & 0.06 & 0.27 & 0.42 & 0.71 & 1,190 \\
\hline 1983 & 0.09 & 0.05 & 0.26 & 0.39 & 0.69 & 1,252 \\
\hline 1984 & 0.09 & 0.06 & 0.25 & 0.39 & 0.72 & 1,313 \\
\hline 1985 & 0.08 & 0.06 & 0.26 & 0.39 & 0.75 & 1,378 \\
\hline 1986 & 0.08 & 0.06 & 0.28 & 0.38 & 0.78 & 1,378 \\
\hline
\end{tabular}

Source: Same as table 5 .

a. Current assets are defined as the sum of cash, receivables, inventories, and other miscellaneous items.

called forth a federal rescue operation. As a result of federal loan guarantees, the firm was able to increase the market value of its debt about 50 percent in 1980 , gradually reducing its debt burden over the following years.

In table 12 both stock and flow measures appear to be useful indicators of corporate financial distress. Chrysler's debt-asset ratio rose from 0.3 in 1972 , to 0.6 in 1973 , to 0.8 in 1974. It then fell below 0.5 in 1976, but rose above 0.6 for the next three years and returned to 1974 levels in 1980 and 1981 when the new, federally guaranteed debt was issued. Since then it has fallen back below 0.4 . The ratio of interest expense to cash flow is a rather noisy series, but it too indicates serious problems in 1978-80. It rose above 1.0 in 1979, and in 1979 and 1980 cash flow was negative. The ratio of interest expense to current assets also deteriorated in 1980.

Equations for Bankruptcy Risk. The solvency and liquidity measures we have presented so far focus on firm liabilities-outstanding debt and interest burden. However, specialists in predicting financial distress or 
Table 10. Ratio of Debt Due in One Year to Total Debt, COMPUSTAT Firms, 1969-86

\begin{tabular}{|c|c|c|c|c|c|c|}
\hline \multirow[b]{2}{*}{ Year } & \multirow{2}{*}{$\begin{array}{c}\text { Full } \\
\text { sample }\end{array}$} & \multicolumn{4}{|c|}{ Percentile } & \multirow{2}{*}{$\begin{array}{l}\text { Number of } \\
\text { firms in } \\
\text { sample }\end{array}$} \\
\hline & & 50 & 90 & 95 & 99 & \\
\hline 1969 & 0.20 & 0.16 & 0.57 & 0.71 & 0.93 & 643 \\
\hline 1970 & 0.22 & 0.15 & 0.56 & 0.69 & 0.87 & 695 \\
\hline 1971 & 0.18 & 0.10 & 0.48 & 0.61 & 0.87 & 747 \\
\hline 1972 & 0.15 & 0.08 & 0.47 & 0.63 & 0.90 & 800 \\
\hline 1973 & 0.16 & 0.11 & 0.48 & 0.67 & 0.92 & 859 \\
\hline 1974 & 0.24 & 0.20 & 0.59 & 0.69 & 0.93 & 902 \\
\hline 1975 & 0.17 & 0.15 & 0.48 & 0.62 & 0.90 & 932 \\
\hline 1976 & 0.15 & 0.12 & 0.45 & 0.64 & 0.92 & 966 \\
\hline 1977 & 0.15 & 0.12 & 0.46 & 0.63 & 0.90 & 1,013 \\
\hline 1978 & 0.16 & 0.13 & 0.47 & 0.61 & 0.90 & 1,051 \\
\hline 1979 & 0.19 & 0.15 & 0.51 & 0.68 & 0.91 & 1,085 \\
\hline 1980 & 0.21 & 0.16 & 0.54 & 0.71 & 0.90 & 1,122 \\
\hline 1981 & 0.22 & 0.18 & 0.59 & 0.72 & 0.91 & 1,169 \\
\hline 1982 & 0.19 & 0.15 & 0.54 & 0.69 & 0.89 & 1,197 \\
\hline 1983 & 0.15 & 0.13 & 0.50 & 0.68 & 0.91 & 1,259 \\
\hline 1984 & 0.17 & 0.14 & 0.57 & 0.73 & 0.96 & 1,321 \\
\hline 1985 & 0.17 & 0.14 & 0.55 & 0.72 & 0.97 & 1,386 \\
\hline 1986 & 0.16 & 0.12 & 0.55 & 0.74 & 0.97 & 1,386 \\
\hline
\end{tabular}

Source: Same as table 5 .

a. At market values. Debt due in one year includes short-term debt and maturing long-term debt.

bankruptcy typically pay at least as much attention to indicators of the fundamental health of the firm's business, such as sales and profits. For example, Altman's "Z-score model" proposes the following indicator of solvency:

$$
Z=1.2 W C T A+1.4 \text { RETA + 3.3EBIT + 0.6 MEBD + 1.0SLTA, }
$$

where $Z$ is the firm's Z-score, WCTA is the ratio of working capital to total assets, RETA is the ratio of retained earnings to total assets, EBIT is earnings before interest and taxes, $M E B D$ is the ratio of the market value of equity to the book value of debt, and $S L T A$ is the ratio of sales to total assets. ${ }^{41}$ Higher Z-scores imply greater solvency. In Altman's sample the average nonbankrupt firm had a Z-score of 4.89 , while the

41. Edward I. Altman, "The Z-Score Bankruptcy Model: Past, Present, and Future," in Altman and Arnold W. Sametz, eds., Financial Crises: Institutions and Markets in a Fragile Environment (John Wiley and Sons, 1977), pp. 89-108. See also chapter 7, "FailurePrediction Models for Nonfinancial Firms," in Altman and others, Applications of Classification Techniques in Business, Banking and Finance (JAI Press, 1981). 
Table 11. Price-Earnings Ratios, COMPUSTAT Firms, 1969-86 ${ }^{a}$

\begin{tabular}{lcccc}
\hline & & \multicolumn{2}{c}{ Percentile } & $\begin{array}{c}\text { Number of } \\
\text { firms in } \\
\text { Yeample }\end{array}$ \\
\cline { 3 - 5 } 1969 & sample & 14.43 & 41.98 & 643 \\
1970 & 16.17 & 15.05 & 79.92 & 695 \\
1971 & 16.81 & 17.25 & 97.59 & 747 \\
1972 & 19.11 & 14.22 & 47.23 & 800 \\
1973 & 16.81 & 7.68 & 27.22 & 859 \\
1974 & 9.95 & 5.35 & 24.58 & 902 \\
1975 & 6.16 & 7.82 & 34.70 & 932 \\
1976 & 8.84 & 8.46 & 19.26 & 966 \\
1977 & 9.13 & 7.85 & 17.72 & 1,013 \\
1978 & 8.26 & 7.11 & 15.88 & 1,051 \\
1979 & 7.48 & 7.38 & 20.18 & 1,085 \\
1980 & 7.73 & 9.09 & 41.72 & 1,122 \\
1981 & 10.15 & 8.36 & 51.29 & 1,169 \\
1982 & 9.00 & 12.67 & $\infty$ & 1,197 \\
1983 & 14.97 & 13.99 & $\infty$ & 1,259 \\
1984 & 15.60 & 11.09 & $\infty$ & 1,321 \\
1985 & 11.56 & 15.74 & $\infty$ & 1,386 \\
1986 & 19.36 & 17.11 & $\infty$ & 1,386 \\
\hline
\end{tabular}

Source: Same as table 5 .

a. Negative values are shown as $+\infty$. Columns for the 95 th and 99 th percentiles are omitted as almost all values are $+\infty$.

average bankrupt firm had a Z-score of -0.26 one year before bankruptcy.

To obtain yet one more measure, albeit crude, of the financial health of the corporate sector, we calculated the distribution of Z-scores for the firms in our growing sample for each year. ${ }^{42}$ The results are reported in table 13. We obtained arithmetic mean Z-scores (not reported) similar to the 4.89 cited by Altman for nonbankrupt firms, although the median and full-sample value-weighted mean scores were somewhat lower. A large fraction of our sample throughout had scores below the 1.81 that Altman used as the cutoff for treating firms as likely bankrupts; this suggests to us that differences in samples and perhaps some small differences in variable definitions make our Z-scores and Altman's not directly comparable. Nevertheless, there may be some information in

42. This certainly stretches the application of Altman's method beyond the purposes for which it was designed. Among other things, it is heroic to assume that the relationship between Z-scores and bankruptcy risk will remain stable over time. (Altman calls this the time series problem; macroeconomists would call it an application of the Lucas critique.) 
Table 12. Stock and Flow Measures of the Financial Condition

of Chrysler Corporation, 1969-86

\begin{tabular}{|c|c|c|c|c|c|}
\hline Year & $\begin{array}{c}\text { Market } \\
\text { value of } \\
\text { debt } \\
\text { (millions } \\
\text { of } \\
\text { current } \\
\text { dollars) }\end{array}$ & $\begin{array}{l}\text { Market } \\
\text { value of } \\
\text { equity } \\
\text { (millions } \\
\quad \text { of } \\
\text { current } \\
\text { dollars) }\end{array}$ & $\begin{array}{l}\text { Debt- } \\
\text { asset } \\
\text { ratio }^{\mathrm{a}}\end{array}$ & $\begin{array}{l}\text { Interest- } \\
\text { cash } \\
\text { flow } \\
\text { ratio }^{\mathrm{b}}\end{array}$ & $\begin{array}{c}\text { Interest- } \\
\text { current } \\
\text { assets }^{\text {ratio }}\end{array}$ \\
\hline 1969 & 1,007 & 1,648 & 0.379 & 0.06 & 0.02 \\
\hline 1970 & 1,062 & 1,386 & 0.434 & 0.12 & 0.02 \\
\hline 1971 & 1,125 & 1,458 & 0.435 & 0.12 & 0.03 \\
\hline 1972 & 1,049 & 2,147 & 0.328 & 0.07 & 0.02 \\
\hline 1973 & 1,252 & 851 & 0.595 & 0.04 & 0.01 \\
\hline 1974 & 1,665 & 422 & 0.798 & 0.61 & 0.05 \\
\hline 1975 & 1,344 & 609 & 0.688 & 0.66 & 0.07 \\
\hline 1976 & 1,186 & 1,228 & 0.491 & 0.17 & 0.05 \\
\hline 1977 & 1,526 & 761 & 0.667 & 0.29 & 0.05 \\
\hline 1978 & 1,179 & 716 & 0.622 & 1.16 & 0.05 \\
\hline 1979 & 1,724 & 768 & 0.692 & $\infty$ & 0.09 \\
\hline 1980 & 2,576 & 600 & 0.811 & $\infty$ & 0.14 \\
\hline 1981 & 1,855 & 469 & 0.798 & 1.62 & 0.16 \\
\hline 1982 & 1,855 & 1,618 & 0.534 & 0.65 & 0.14 \\
\hline 1983 & 1,412 & 3,613 & 0.281 & 0.20 & 0.10 \\
\hline 1984 & 718 & 4,226 & 0.145 & 0.07 & 0.05 \\
\hline 1985 & 2,612 & 4,721 & 0.356 & 0.11 & 0.05 \\
\hline 1986 & 2,860 & 5,345 & 0.349 & 0.19 & 0.08 \\
\hline
\end{tabular}

Source: Authors' calculations using the COMPUSTAT data base.

a. Ratio of total market value of debt to total market value of assets.

b. Ratio of interest expense to operating income before depreciation, taxes, and interest expense. Negative values and values greater than 100 are shown as $+\infty$.

c. Current assets are defined as the sum of cash, receivables, inventories, and other miscellaneous items.

the year-to-year movements of our variable. The main results suggested by table 13 are that, according to this particular solvency measure, there has been little in the way of secular deterioration in the condition of the typical firm; however, there does appear to have been sor e tendency to decline recently, especially at the low end of the distribution.

\section{Corporate Financial Trends by Industry}

In this section we break our sample of COMPUSTAT firms into industrial groups, roughly SIC two-digit industries, with some of the smaller industries merged, as described in table 14. Industry-specific 
Table 13. Altman's Z-Ratio, COMPUSTAT Firms, 1969-86 ${ }^{\mathrm{a}}$

\begin{tabular}{|c|c|c|c|c|c|c|}
\hline \multirow[b]{2}{*}{ Year } & \multirow{2}{*}{$\begin{array}{c}\text { Full } \\
\text { sample }\end{array}$} & \multicolumn{4}{|c|}{ Percentile } & \multirow{2}{*}{$\begin{array}{l}\text { Number of } \\
\text { firms in } \\
\text { sample }\end{array}$} \\
\hline & & 1 & 5 & 10 & 50 & \\
\hline 1969 & 3.34 & 0.81 & 1.06 & 1.37 & 3.99 & 641 \\
\hline 1970 & 3.29 & 0.81 & 1.12 & 1.33 & 3.64 & 693 \\
\hline 1971 & 3.52 & 0.79 & 1.16 & 1.36 & 3.93 & 745 \\
\hline 1972 & 3.78 & 0.73 & 1.15 & 1.36 & 3.95 & 795 \\
\hline 1973 & 3.60 & 0.61 & 1.04 & 1.24 & 3.40 & 857 \\
\hline 1974 & 3.09 & 0.59 & 0.87 & 1.11 & 3.21 & 900 \\
\hline 1975 & 3.06 & 0.61 & 1.03 & 1.25 & 3.38 & 927 \\
\hline 1976 & 3.30 & 0.82 & 1.16 & 1.42 & 3.84 & 961 \\
\hline 1977 & 3.16 & 0.88 & 1.27 & 1.48 & 3.71 & 1,004 \\
\hline 1978 & 3.10 & 0.91 & 1.20 & 1.46 & 3.70 & 1,044 \\
\hline 1979 & 3.16 & 0.88 & 1.17 & 1.51 & 3.93 & 1,077 \\
\hline 1980 & 3.28 & 0.90 & 1.18 & 1.60 & 4.01 & 1,114 \\
\hline 1981 & 3.03 & 0.86 & 1.18 & 1.54 & 3.85 & $i, 156$ \\
\hline 1982 & 3.01 & 0.77 & 1.16 & 1.48 & 3.81 & 1,183 \\
\hline 1983 & 3.30 & 0.66 & 1.18 & 1.52 & 4.14 & 1,245 \\
\hline 1984 & 3.22 & 0.39 & 1.18 & 1.49 & 3.88 & 1,307 \\
\hline 1985 & 3.22 & 0.07 & 1.06 & 1.48 & 3.71 & 1,365 \\
\hline 1986 & 3.15 & -0.43 & 1.00 & 1.38 & 3.51 & 1,368 \\
\hline
\end{tabular}

Source: Same as table 5 .

a. The Z-ratio is defined in the text. Higher values imply greater solvency.

data enable us to address three concerns about the results in the previous section.

First, although there is no clear upward trend in aggregate debt-asset measures, there could be strong trends in some industrial groups. A concentration of debt in a few industries would justify concern about the possible effects of an adverse industry-specific shock.

Second, shifts in the industrial composition of our COMPUSTAT sample could conceal increases in debt-asset ratios. If industries with low debt-asset ratios have gained a larger weight in our sample over time, either by growth in the number of firms for the equal-weighted distribution, or by growth in market value for the value-weighted distribution, then it is possible in principle for debt-asset ratios to increase in every industry, but for our aggregate measures to remain constant. ${ }^{43}$

Third, we have not yet tried to take into account changes over time in

43. Note, however, that in this situation our equal-weighted results for a fixed sample of firms would detect the increase. In fact those results are very similar to the ones reported in table 5. 
Table 14. Debt-Asset Ratios, COMPUSTAT Firms, by Industry, Selected Periods, 1969-86a

\begin{tabular}{|c|c|c|c|c|c|c|}
\hline Industry & $1969-74$ & $1975-80$ & $1981-86$ & 1984 & 1985 & 1986 \\
\hline \multicolumn{7}{|l|}{ Total } \\
\hline Market-value weight ${ }^{b}$ & 0.273 & 0.334 & 0.313 & 0.312 & 0.304 & 0.313 \\
\hline Fixed 1969-74 weight ${ }^{\mathfrak{c}}$ & 0.273 & 0.303 & 0.303 & 0.307 & 0.301 & 0.315 \\
\hline Fixed 1986 weight $^{d}$ & 0.298 & 0.322 & 0.308 & 0.309 & 0.302 & 0.313 \\
\hline \multicolumn{7}{|l|}{ Market-value weight } \\
\hline excluding oile & 0.295 & 0.360 & 0.308 & 0.299 & 0.290 & 0.309 \\
\hline Laboratory equipment & 0.098 & 0.188 & 0.220 & 0.251 & 0.230 & 0.239 \\
\hline Printing and publishing & 0.124 & 0.144 & 0.120 & 0.089 & 0.123 & 0.159 \\
\hline Electronics & 0.161 & 0.162 & 0.141 & 0.137 & 0.139 & 0.173 \\
\hline Paper & 0.170 & 0.221 & 0.238 & 0.262 & 0.255 & 0.276 \\
\hline Chemicals and pharmaceuticals & 0.174 & 0.232 & 0.203 & 0.193 & 0.184 & 0.186 \\
\hline Petroleum and natural gas & 0.194 & 0.163 & 0.338 & 0.357 & 0.364 & 0.464 \\
\hline Petroleum refining & 0.211 & 0.258 & 0.323 & 0.349 & 0.348 & 0.314 \\
\hline Mining $f$ & 0.225 & 0.312 & 0.364 & 0.391 & 0.348 & 0.364 \\
\hline Food and tobaccos & 0.227 & 0.244 & 0.224 & 0.208 & 0.233 & 0.241 \\
\hline Retail $^{\mathrm{h}}$ & 0.229 & 0.312 & 0.247 & 0.235 & 0.217 & 0.226 \\
\hline Lumber and furniture ${ }^{i}$ & 0.246 & 0.241 & 0.271 & 0.263 & 0.279 & 0.294 \\
\hline Machinery & 0.254 & 0.264 & 0.282 & 0.288 & 0.268 & 0.306 \\
\hline Glass and concrete & 0.254 & 0.347 & 0.343 & 0.318 & 0.330 & 0.439 \\
\hline Vehicles & 0.266 & 0.280 & 0.264 & 0.211 & 0.223 & 0.286 \\
\hline Apparel & 0.283 & 0.323 & 0.229 & 0.279 & 0.173 & 0.229 \\
\hline Metal products & 0.303 & 0.282 & 0.264 & 0.277 & 0.308 & 0.321 \\
\hline Rubber and plastics & 0.318 & 0.414 & 0.281 & 0.257 & 0.228 & 0.273 \\
\hline Construction ${ }^{\mathrm{j}}$ & 0.335 & 0.305 & 0.321 & 0.348 & 0.286 & 0.377 \\
\hline Wholesale $^{k}$ & 0.373 & 0.378 & 0.262 & 0.235 & 0.243 & 0.289 \\
\hline Textiles & 0.442 & 0.546 & 0.384 & 0.420 & 0.402 & 0.376 \\
\hline Steel refining & 0.453 & 0.430 & 0.437 & 0.475 & 0.474 & 0.442 \\
\hline Transportation ${ }^{1}$ & 0.475 & 0.517 & 0.432 & 0.407 & 0.404 & 0.466 \\
\hline Utilities & 0.501 & 0.527 & 0.493 & 0.489 & 0.488 & 0.484 \\
\hline Communications & 0.513 & 0.479 & 0.382 & 0.378 & 0.340 & 0.347 \\
\hline Number of firms in sample & 883 & 1,096 & 1,346 & 1,283 & 1,346 & 1,346 \\
\hline
\end{tabular}

Source: Authors' calculations using the COMPUSTAT data base.

a. The numbers in this table are value-weighted mean debt-asset ratios, by industry and weighting across industries

b. Weights each industry by its current share in total market value. (The numbers differ from those in table 4 because some small industries have been excluded.)

c. Uses fixed 1969-74 value weights.

d. Uses fixed 1986 value weights.

e. Excludes oil-related industries, SIC codes 13 and 29.

f. SIC codes 10, 12, and 14 .

g. SIC codes 20 and 21 .

h. SIC codes 52-59.

i. SIC codes 24 and 25.

j. SIC codes 15-17.

k. SIC codes 50 and 51 .

l. SIC codes $40-45$ and 47. 
the variables that determine debt-asset ratios. If variables that are historically associated with high debt-asset ratios have been unusually low in recent years, then one would expect debt-asset ratios to fall. In this situation, constant debt-asset ratios might nevertheless indicate deteriorating corporate financial conditions.

In table 14 we present evidence that is relevant for the first two of these issues. We calculate value-weighted mean debt-asset ratios, using our growing sample of firms, for each industrial group. From these ratios, we compute value-weighted aggregate measures in several different ways: using own-year value weights; using 1969-74 average and 1986 value weights to fix the industry composition of the sample; and using own-year value weights excluding oil-related industries (SIC codes 13 and 29) that have behaved unusually in the 1980s.

The aggregate measures tell a fairly consistent story. Debt-asset ratios have increased in recent years, but even at the end of 1986 they were not extraordinarily high relative to ratios during $1975-80$. This holds true whether we allow industrial composition to change through the sample by using own-year weights or fix the composition at 1969-74 or 1986 values, and whether we include or exclude the oil-related industries. ${ }^{44}$

The industry-specific debt-asset ratios reveal striking changes in leverage in a few industries. The most dramatic example is the petroleum and natural gas industry (SIC 13), whose value-weighted mean debtasset ratio rose from an average of 0.194 in 1969-74 to an average of 0.338 in 1981-86, reaching 0.364 in 1985 and 0.464 in 1986. Mining (SIC 10), petroleum refining (SIC 29), paper (SIC 26), glass and concrete (SIC 32), and laboratory equipment (SIC 38) also had increasing debt-asset ratios. But these were among the less levered industries in 1969-74, while the five most highly levered industries in that period-textiles (SIC 22), steel refining (SIC 33), transportation (SIC 40), utilities (SIC 49), and communications (SIC 48)-all experienced declining debt-asset ratios from 1969-74 through 1986. Thus the right tail of the industry debt-asset distribution does not seem to have increased.

Our industry data panel can also be used to estimate a simple model of the determinants of debt-asset ratios. In this way we can try to take account of some of the forces that may have encouraged or discouraged corporate debt issuance over the sample period.

44. It also holds true in our fixed sample of 643 firms. 
We estimate a familiar partial-adjustment model for debt issue. The dependent variable is an industry's net issue of debt-the change in the book value of debt or, equivalently, new issue less estimated maturing debt from the BSW method. We have

$$
\Delta D_{i t}=\lambda\left[M_{i t}^{*}-\left(M_{i t}-\Delta D_{i t}\right)\right]+u_{i t},
$$

where $\Delta D_{i t}$ is the net issue of industry $i$ in year $t, \lambda$ is a partial adjustment parameter, $M_{i t}^{*}$ is the target market value of debt for the end of year $t$, and $M_{i t}$ is the actual market value of debt at the end of year $t$. (Thus $M_{i t}-\Delta D_{i t}$ is the market value of debt that the industry would have at the end of the year if it refinanced maturing debt but took no other action. $)^{45}$

In estimation we scale the equation by the end-of-year market value of assets, $A_{i t}$, both to reduce heteroskedasticity and because it is natural to think of the industry as having a target ratio $M_{i t}^{*} / A_{i t}{ }^{46} \mathrm{We}$ model the target ratio as a linear function of industry dummies, time dummies, and several variables that vary over both industries and time. The latter include $O P I N C$, the ratio of after-tax earnings plus interest paid to the market value of assets; $C A S H$, the ratio of cash and receivables to the market value of assets; INVENT, the ratio of inventories to the market value of assets; PLANT, the ratio of plant and equipment to the market value of assets; $O T H$, the ratio of other current assets to the market value of assets; GSALES, the real growth rate of industry sales measured from the previous year to the current year; and SIGMA, the log standard deviation of sales growth across firms within the industry. ${ }^{47}$ The time dummies are included to allow for aggregate movements in debt-asset ratios that are not explainable by the industry-specific variables.

We think of OPINC and GSALES as measures of corporate liquidity that might affect the ability of firms to issue new debt. On this interpretation we expect them to enter the equation with a positive sign. We note, however, that low values of OPINC and GSALES might also reflect a temporary cash-flow deficit that would cause firms to issue more

45. We obtained similar results when we estimated a variant of this model that assumes that the industry controls the market value of its debt directly. The dependent variable in the alternative model is $\Delta M_{i t}$ and the right-hand-side variable is $M_{i t}^{*}-M_{i, t-1}$.

46. We estimate the equation using our fixed sample of firms, rather than the growing sample used in table 13, because there are some sudden changes in industry market values in the growing sample as new firms enter the sample.

47. The various asset ratios are all value-weighted measures that effectively treat the industry as a single firm. SIGMA is a value-weighted standard deviation. 
debt to meet planned dividend payments and investment expenses. ${ }^{48}$ If this effect is important, OPINC and GSALES might enter with a negative sign.

CASH, INVENT, PLANT, and $O T H$ are all variables that measure the collateral of an industry relative to the market value of its assets. We expect that industries with high collateral (such as the utility industry, a traditional high-leverage industry) are able to issue more debt relative to market-value assets. The sum of the collateral variables is the ratio of book assets to the market value of assets-roughly, the reciprocal of Tobin's $q$.

Finally, SIGMA is included as a rough measure of the riskiness of an industry at a particular time, and therefore of the expected bankruptcy costs associated with a given level of debt. We expect SIGMA to enter the equation with a negative sign.

The reduced-form equation we estimate, omitting the constant, time, and industry dummies, is

$$
\begin{aligned}
\Delta D_{i t} / A_{i t}= & -0.409 \text { MDEBT }+0.042 \text { OPINC }-0.187 \text { CASH } \\
& (0.043) \quad(0.114) \quad(0.056) \\
& +0.183 \text { INVENT }+0.222 \text { PLANT }+0.204 \text { OTH } \\
& (0.053) \quad(0.034) \quad 0.068) \\
& +0.017 \text { GSALES }+0.002 \text { SIGMA }+u_{i t},
\end{aligned}
$$

where $M D E B T$ is the market value of debt (standard errors are in parentheses). The estimate of the partial adjustment parameter $\lambda,-0.409$, is quite plausible and has a low standard error. Of the other variables, we find that high ratios of inventory, plant and equipment, and other book assets to the market value of assets tend to raise the desired level of the market debt-asset ratio. A high ratio of cash to market assets tends to lower debt issue, other things equal. The other variables do not have a strong effect on debt issue.

One interesting feature of the results is the pattern of estimated time effects. The sums of the time dummy coefficients over the periods 1970$74,1975-80$, and $1981-86$ are $0.210,-0.101$, and -0.109 , respectively. (The coefficients are normalized in such a way that they average to zero

48. Alan Auerbach, "Real Determinants of Corporate Leverage," in Friedman, Corporate Capital Structure, pp. 301-22, includes a variable of this sort. 
over the entire sample period.) In 1984, 1985, and 1986 the estimated time dummies are $-0.026,-0.011$, and 0.028 . These estimates imply that the growth in debt over the 1980 s as a whole, including the high levels of repurchases in 1984 and 1985, is well explained by the other variables in the equation and has not been unusual in that sense. However, debt did grow unusually rapidly in 1986 . The estimated positive coefficients on INVENT, PLANT, and $O T H$ may also contribute to the high 1986 dummy, since the increase in stock market values in 1984 and 1985 lowered these variables in 1986 and would normally have been expected to lower debt issue relative to the market value of assets. To this extent there may be some truth to the view that constant market debt-asset ratios, in a period of rapidly rising stock market prices, are historically unusual and suggest deteriorating corporate financial conditions.

\section{Effects of the Market Crash}

The final item on our agenda is to evaluate the effect of unfavorable macroeconomic developments on corporate financial conditions. We begin by studying the effect of the October 1987 stock market crash on the market-value debt-asset ratios of firms in our sample. Our focus is not on debt-asset ratios during the crash itself, but rather on the corporate debt situation in the aftermath of the decline, at the end of 1987.

As a first approximation, one might expect to find only a small effect of the events of 1987 on market-value debt-asset ratios. Most broad common stock indexes were only slightly lower at the end of 1987 than at the end of 1986, because the October crash was preceded by a dramatic increase in stock prices. It is possible, however, that the distribution of market-value debt-asset ratios moved adversely in 1987. In particular, if the stock prices of more highly levered industries, or more highly levered firms within each industry, fell more than those of others during the year, then the right tail of the debt-asset distribution could have shifted out.

Because our COMPUSTAT data end in 1986, we can construct only rather crude estimates of end-1987 debt-asset ratios. We collected data from the Wall Street Journal on end-1987 common stock prices for 1,230 firms. Then we computed market-value debt-asset ratios using these 
Table 15. Debt-Asset Ratios after the Stock Market Crash of 1987, COMPUSTAT Firms ${ }^{a}$

\begin{tabular}{lccccc} 
& Full & \multicolumn{4}{c}{ Percentiles } \\
\cline { 3 - 6 } Year and change & sample & 50 & 90 & 95 & 99 \\
\hline 1986 & 0.295 & 0.328 & 0.612 & 0.709 & 0.797 \\
1987 & 0.348 & 0.386 & 0.729 & 0.808 & 0.925 \\
Absolute change & 0.053 & 0.058 & 0.117 & 0.099 & 0.128 \\
Percentage change & 18.0 & 17.7 & 19.1 & 14.0 & 16.1 \\
\hline
\end{tabular}

Source: Authors' calculations using the COMPUSTAT data base and end-of-the-year equity prices from the Wall Street Journal.

a. In this table the sample consists of 1,230 firms for which we were able to obtain equity prices as of the end of 1987.

prices and measures of the market value of debt based on end-1987 interest rates and end-1986 book values of debt.

In table 15 we report debt-asset ratios for our 1,230 firms, both in aggregate, as we did in table 4 , and by percentile of the distribution of debt-asset ratios, as we did in table 5. The aggregate value-weighted mean debt-asset ratio increased from 0.295 at the end of 1986 to 0.348 at the end of 1987 , a rise of 0.053 . This is a noticeable increase, although the end-1987 value is still comparable to or below the levels reached by the value-weighted mean of our varying sample in several years in the seventies (1974, 1977, and 1978). There is also some evidence of a tail effect in the absolute changes; the median debt-asset ratio rose 0.058 , or 17.7 percent, and the higher percentiles of the distribution rose even more. The higher percentiles at the end of 1987 seem to be comparable to those reached at the previous peak in 1974. These numbers are particularly striking because they ignore any net debt issue that may have occurred in 1987.

\section{RISKS FROM RECESSION}

A prime concern of those who have called attention to the dangers of corporate leverage is that U.S. corporations are now more vulnerable to a recession than they were in earlier decades. ${ }^{49}$ Debt-asset ratios were lower in 1986 than in 1974, but the latter was a recession year; if a

49. Friedman, "Increasing Indebtedness and Financial Stability in the United States"; Kaufman, "Debt: The Threat to Economic and Financial Stability." 


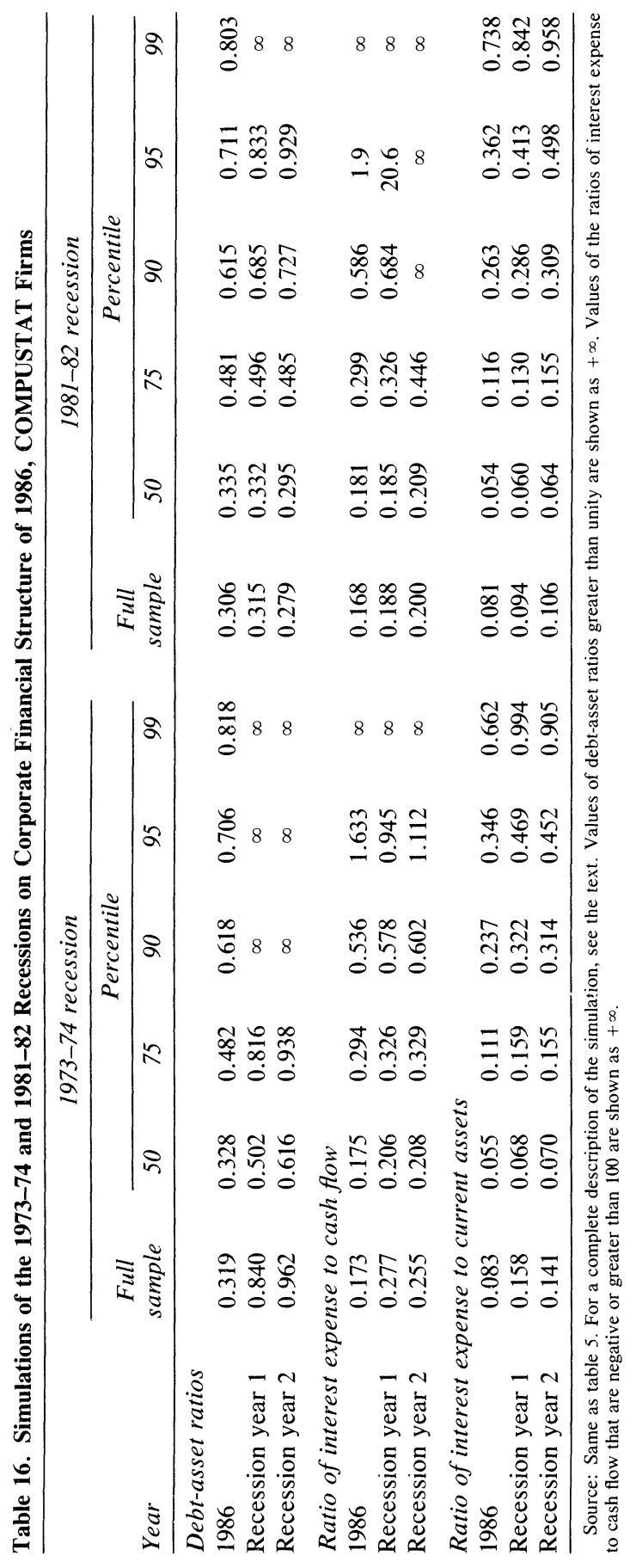


recession hit today the ratios might well rise beyond their previous peak levels.

To get a sense of the potential effects of a recession on corporate financial structure, we simulated the effects of recessions like those of 1973-74 and 1981-82. For each firm that existed in the base year, 1972 or 1980 , we computed the percentage changes in the total market value of the firm that were actually observed over the two succeeding years, which we call recession year 1 and recession year $2 .{ }^{50} \mathrm{We}$ also computed the changes in the book value of the firm's debt and applied these same changes, scaled up by the book value of the firm's assets, to the corporate financial conditions of 1986. Using the BSW method and historical changes in interest rates from the appropriate recession, we were able to calculate market-value debt-asset ratios for each firm in two hypothetical years following 1986 on the assumption that changes from the earlier recession experience were duplicated. In a parallel way we also calculated the ratios of interest expense to cash flow and to current assets for each firm. ${ }^{51}$ The simulation results are reported in table 16 for both the 1973-74 recession and the 1981-82 recession.

The most dramatic deterioration in debt-asset ratios occurs in the simulation of the 1973-74 recession. During 1973-74 the total market value of COMPUSTAT firms dropped sharply. In 1986 these firms are more highly leveraged, so their debt-asset ratios are high to begin with and are more severely affected by a given drop in total market value. A repetition of the 1973-74 fall in total market value would lead to unprecedented debt-asset ratios. In fact, for at least 10 percent of firms the simulated debt-asset ratios exceed unity, indicating bankruptcy. The median debt-asset ratio reaches 0.616 as compared with a previous peak of 0.532.52 The ratios of interest expense to cash flow and to current assets do not change as dramatically.

In the 1981-82 recession, by contrast, the stock market was relatively stable and interest rates were high, reducing the market value of debt.

50. The 1986 starting statistics differ for the two simulations because the firms in the 1972 and 1980 samples differ.

51. We took observed changes in earnings and current assets from the historical recessions and scaled them up by the book value of the firm's assets. We used BSW measures of interest expenses.

52. The full-sample debt-asset ratio reaches 0.962 , but this number should be treated with caution since it is greatly affected by the firms with ratios greater than unity. This is also why the full-sample ratios often differ substantially from the 50th percentile values. 
The results in the table reflect this fact; the full-sample and median debtasset ratios do not change much, although there is some deterioration in the higher percentiles of the distribution. Since earnings fall and interest rates rise in the simulation, however, the ratios of interest expense to cash flow and to current assets deteriorate sharply, particularly for firms above the median.

\section{Conclusion: How High Is High?}

Recent concern about excessive corporate debt appears to be based on high growth rates of aggregate corporate debt, measured at book value, relative to the growth rates of sales and gross income. In this paper we have measured corporate debt relative to the corporate assets available to support it, using estimates of market values of debt and assets to supplement book values. In our sample of COMPUSTAT firms, we find little evidence of an upward trend in corporate debt-asset ratios, whether they are measured at book values or at market values. Debtasset ratios did rise in 1986, but even at the end of 1986 were well below the high levels reached in 1974-75.

We have also studied the cross-sectional distribution of debt-asset ratios by firm and by industry. The 90th, 95th, and 99th percentiles of the distribution of debt-asset ratios do not seem to have increased faster than the median ratio in the eighties; thus there has been no clear tendency for the upper tail of the debt-asset distribution to increase. There are some striking changes in the relative leverage of different industries, but there has been no tendency for debt-asset ratios to increase in traditionally high-leverage industries. All in all, corporate financial conditions, as reflected in this measure of solvency, seem relatively stable in recent years.

By contrast, we find deterioration during the eighties in some measures of corporate liquidity, such as the ratios of interest expense to cash flow and current assets. The solvency and liquidity measures diverge in the eighties because of the substantial rise in corporate price-earnings ratios that increases our measure of assets in debt-asset ratios.

For several reasons, we choose to emphasize the signs of corporate financial stress over the measures that suggest that corporate financial conditions are fairly normal. First, a comparison of 1986 with 1974 is a 
comparison of a normal year with a recession year. If a recession were to occur today, particularly if it were accompanied by a substantial drop in the stock market, debt-asset ratios measured at market value would rise dramatically. We find some evidence that the upper tail of the debtasset distribution has increased in the aftermath of the stock market crash of 1987; and when we simulate a recession like that of 1973-74, we find that debt-asset ratios rise to unprecedented levels, implying bankruptcy for more than 10 percent of our sample of firms. Second, in a recession or financial crisis, corporate liquidity may become more important; a solvent but illiquid corporation may be forced into bankruptcy if it is temporarily unable to roll over its debt.

A caveat applies to all the results we have reported. Although we can measure trends in aggregate financial ratios, in the end we have no reliable metric of whether these ratios are in some absolute sense too high or too low. The natural tendency is to try to make judgments about the aggregate ratios based on analogies with the historical experiences of individual firms, as we did when we compared 1969-86 aggregate financial ratios with those of Chrysler Corporation. Using the experience of individual firms to interpret changes in aggregate financial ratios, however, may be fallacious. While the deterioration of a firm's financial ratios relative to prevailing norms is probably bad news for the firm, changes in the norms themselves may reflect only changes in the regulatory and financial environment.

The effect of a change in norms on aggregate riskiness depends on why the norms changed, which may be hard to ascertain. The distinction between changes in the condition of an individual firm and changes in norms is most striking in international comparisons. Debt-asset ratios of Japanese corporations, for example, are twice those of their U.S. counterparts; the difference is due to institutional arrangements, such as the particular structure of the Japanese banking system, and does not imply that Japanese firms on average are riskier..$^{53}$

On the other hand, if one wants to make the case that norms have changed, so that acceptable levels of corporate risk can be achieved with greater interest burdens than before, it is important to pinpoint the changes in financial market conditions or practices that are supposed to

53. Albert Ando and Alan Auerbach, "The Cost of Capital in the U.S. and Japan: A Comparison" (University of Pennsylvania, January 1988). 
have brought about the change. Two suggestions have been made to us: the emergence of the junk bond market and of corporate pension overfunding. ${ }^{54}$

The junk bond argument is that these bonds represent a financial innovation that allows firms to issue more debt without increasing risk. This might be true, for example, if junk bonds were held primarily by insiders who could be counted on to renegotiate rather than force bankruptcy. Junk bonds would then be like equity, only relabeled, presumably for tax purposes.

However, there is little evidence that the emergence of junk bonds has changed the meaning of standard financial ratios. ${ }^{55}$ First, junk bonds make up only a small part of total corporate debt; although constituting about 20 percent of corporate bonds outstanding in 1986, junk bonds account for well under 10 percent of nonfinancial corporate debt, including bank loans and short-term debt. ${ }^{56}$ Second, junk bond issues have increased largely at the expense of bank loans to corporations. As such, they are part of the general trend toward "securitization" of traditionally intermediated instruments. Because junk bonds tend to be held by mutual funds, insurance companies, and other institutions, it seems likely that their expanded use has increased rather than reduced the difficulty of avoiding bankruptcy through negotiation. Finally, far from being an innovation, low-grade bonds were used extensively in the 1920 s.

The pension fund argument is that high levels of overfunding may have given corporations the flexibility needed to take on more debt safely. This may have been true as late as 1984 , but in more recent years falling interest rates have increased the present value of pension liabilities and eliminated this surplus. ${ }^{57}$ Thus changes in net pension obligations, which are not included in our measures of debt, probably do not rationalize higher interest burdens.

54. By Lawrence Summers and Sanford Grossman, respectively.

55. This paragraph relies heavily on Kevin Perry and Robert Taggart, "The Growing Role of Junk Bonds in Corporate Finance," Continental Bank Journal of Applied Corporate Finance (forthcoming).

56. Junk bonds outstanding were $\$ 125$ billion at the end of 1986 ; according to the Flow of Funds Accounts, credit market instruments of nonfinancial corporations at that time amounted to $\$ 1,711$ billion. Also, about one-third of the junk bonds were "fallen angels," bonds issued at investment grade that were subsequently downgraded.

57. Chuck Paustian, "\$200 Billion Surplus Wiped Out," Pension and Investment Age, July 7, 1986. We are grateful to Jeremy Bulow for this reference. 
We conclude that although it is important to consider the possibility that norms in corporate finance have changed, we have no good account of why they may have done so. In the absence of strong evidence for a change in norms, it seems appropriate to be concerned about the historically unusual trends in corporate finance during the 1980s. In particular, the continued financial health of the corporate sector seems to require that the strong earnings growth forecast by the stock market actually take place. Should this earnings growth fail to materialize, measures of corporate financial stress could reach unprecedented levels. 


\section{Comments and Discussion}

Benjamin M. Friedman: Ben Bernanke and John Campbell conclude that "it seems appropriate to be concerned" about the current corporate debt situation in the United States, and I agree. While we do not yet have the corporate debt "crisis" about which they ask in their title, I believe-even more so than they-that we have a corporate debt problem, and a potentially serious one at that. The heart of the problem is the increased financial fragility that has resulted from the massive borrowing campaign upon which American business corporations have embarked since the current economic expansion began in 1983. A major strength of the Bernanke-Campbell paper is its focus, which I would have liked to be still sharper, on the fact that "the continued financial health of the corporate sector seems to require that the strong earnings growth forecast by the stock market actually take place."

Although popular discussion of debt problems has devoted more attention to consumer debt, exploiting the myth of the "me generation" to highlight, and often exaggerate, how much individuals have borrowed, Bernanke and Campbell are right in looking instead at business debt. While both households and businesses have borrowed in record volume during the 1980s, on the whole they have done so for different purposes. Households have built up record debt levels relative to their incomes, but at the same time they have built up record asset levels, including not just equities and other assets exhibiting high price volatility, but also liquid assets and other stable-price debt instruments. As a result, aggregate household net worth compared with gross national product has shown no deterioration since 1980 , and that remains true after the October 19 stock market collapse. By contrast, as the "supply-side" promises and premises that motivated this decade's economic policies have crumbled into dust, business investment in the 1980s has been 
weaker than in any sustained period since World War II. Increasingly during the 1980s, American business corporations have borrowed not to invest, in either tangible or financial assets, but simply to pay down their own or other corporations' equity. As a result, the corporate sector's aggregate net worth has declined not just in comparison with gross national product, but absolutely. ${ }^{1}$

Even so, as Bernanke and Campbell rightly point out, the potential problem lies not with business solvency but with business liquidity. The deterioration in the corporate sector's interest coverage is striking. Since 1980 it has consistently taken more than 50 cents of every dollar of the average nonfarm nonfinancial corporation's pretax earnings just to pay its interest bill. That is a far cry from the 1950s and 1960s, when interest payments took just 16 cents of each dollar of earnings on average, or even the 1970s, when interest payments took 33 cents on average. Moreover, instead of improving, as the continuing economic expansion boosted earnings and as interest rates declined, corporations' interest coverage eroded further in both 1985 and 1986. Bernanke and Campbell's table 6 relates interest expense to cash flow rather than just earnings, but the increase in the 1980s is still apparent. If the highly useful percentile breakdowns that Bernanke and Campbell present for their sample of corporations are indicative of the distribution for the universe of all nonfinancial corporations, they suggest very narrow interest coverage indeed for many firms. ${ }^{2}$ It is not surprising, therefore, that the economic expansion that began in 1983 has been the only expansion since World War II to bring with it a rising, rather than falling, rate of business bankruptcies and debt defaults.

1. As of year-end 1980, the net worth of the U.S. nonfarm nonfinancial corporate business sector, as calculated in the Federal Reserve System's Flow of Funds Accounts (that is, with liabilities and debt assets valued at par, reproducible tangible assets valued at reproduction cost, the land valued at market) was 91.4 percent of fourth-quarter 1980 GNP. By year-end 1986 the comparable ratio was 76.3 percent.

2. Bernanke and Campbell's sample apparently includes primarily mature firms that pay more dividends, and rely less on borrowing, than the average nonfarm nonfinancial business corporation. Firms in the sample also account for a disproportionately small share of corporate equity repurchases. For 1986 , for example, table 2 reports $\$ 38.1$ billion of dividend payments, which compares with $\$ 95.7$ billion for the nonfarm nonfinancial business sector as a whole (from the Flow of Funds Accounts). By contrast, in 1986 firms in the sample raised just $\$ 39.6$ billion from net debt issues, as against $\$ 190.2$ billion for the sector overall, and repurchased only $\$ 7.3$ billion of equity, as against $\$ 76.5$ billion for the sector overall. 
The typical answer to all this is-or, at least until October 19, wasthat debt levels and interest burdens are high compared with today's earnings but not in relation to the earnings that American business is likely to enjoy in the not-very-distant future: that our economy has entered a new era of stability and rapid growth, which soon enough will deliver the higher earnings needed to service the debts of all but the usual small percentage of corporations that are obviously mismanaged or extraordinarily unfortunate. For observers naturally inclined to accept as optimal whatever debt levels corporate managers have taken on, as long as the reorganizations and recapitalizations that gave rise to all this borrowing resulted from private responses to profit-maximizing incentives, the evidence for this optimistic view was high and rising stock prices-which, according to this view, merely discount future earnings in the most efficient way imaginable, and therefore provide the best available estimate of what those future earnings will be.

The crash has changed all that. Figure 1 plots the ratio of debt (at book value) to equity (at market value) for the nonfarm nonfinancial corporate business sector. ${ }^{3}$ The solid line through 1986 indicates yearend values of the debt-equity ratio calculated directly from the Flow of Funds Accounts. I have also added several points for 1987, including the August 25 stock market peak as well as October 19, based on an interpolation of the quarterly Flow of Funds corporate borrowing data for 1987, in conjunction with a simple equation I estimated to relate the Standard and Poor's stock price index (published daily) to the Flow of Funds estimate of the market value of equity for the entire nonfarm nonfinancial corporate business sector. ${ }^{4}$ I have also added in the figure a value of the debt-equity ratio for March 31, 1988, based on an extrapolation of the pace of corporate borrowing during the latter half of last year, and closing stock prices for March 31.

The resulting data speak for themselves, and I will not dwell on

3. I believe that the book-to-market correction for debt is less important than Bernanke and Campbell, and many others, suggest. One reason is the callability, typically after some deferment period, of most of the corporate debt that does not bear an explicitly floating interest rate anyway. Another reason is that interest levels today are not far from the relevant mean for evaluating the fixed-rate corporate debt now outstanding. Some empirical evidence also suggests that, at least in the aggregate, fluctuations in market values relative to par values have not changed the total of corporate debt outstanding much compared with the questions at issue here.

4. The simple correlation between these two variables is 0.98 . 
Figure 1. Debt-Equity Ratio, U.S. Nonfarm Nonfinancial Corporate Business Sector, 1947-86, and Selected Dates, 1987-88 ${ }^{\mathrm{a}}$

Percent

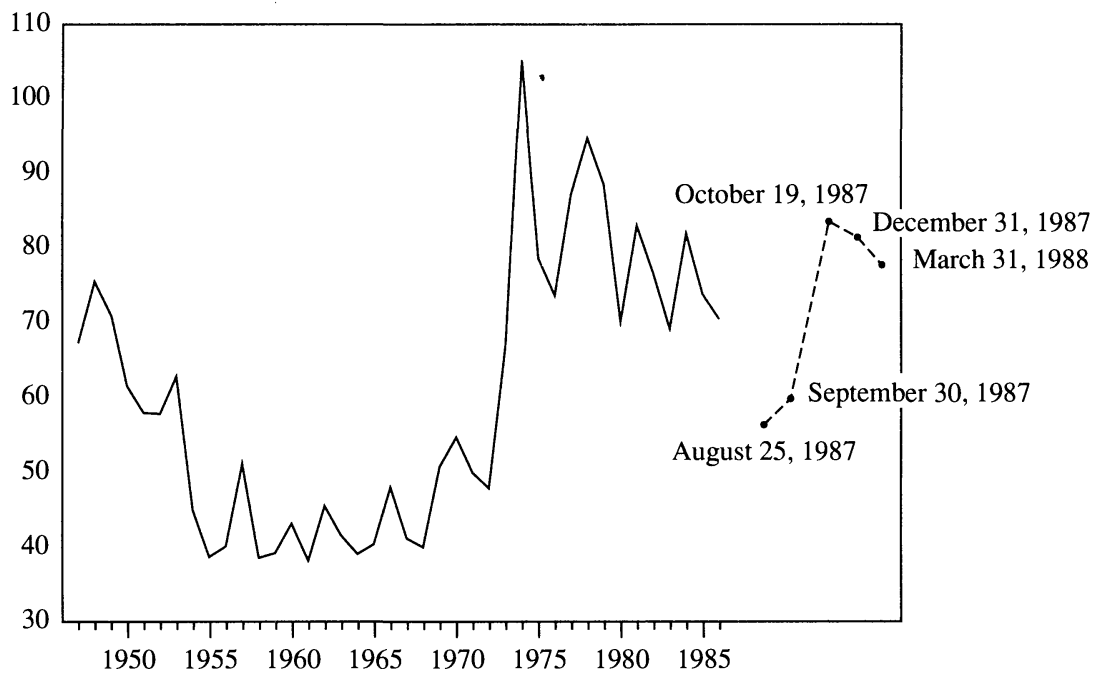

Source: Board of Governors of the Federal Reserve System, Flow of Funds Accounts, various issues, and author's calculations.

a. The ratio, expressed as a percent, of the book value of debt to the market value of equity. Data through 1986 are year-end values. Selected ratios for 1987 and 1988 were estimated by the author (see text description).

whether this particular glass is half full or half empty. Either way, the central point bearing on the questions at issue in Bernanke and Campbell's paper is that the principal empirical foundation for the optimism about corporations' debt burdens in relation to likely future earnings, which was often expressed just a short time ago, has now disappeared.

That all this has happened during a period of sustained economic expansion is itself interesting enough. But as Bernanke and Campbell appropriately recognize, the real question is what would happen if, at some time in the near future, we should experience a recession of any significant severity. The simulations that Bernanke and Campbell present in table 16 address this question directly, and the results are hardly reassuring. I take these results to be highly supportive of just the fears that those of us who have expressed concern about the corporate debt problem have had in mind. In the event of a significant recession-like that of 1973-75 or 1981-82-an unusually large number of corporations will be unable to meet their obligations. Firms whose own business is 
otherwise sound may therefore find themselves threatened on account of the failure of their customers and their suppliers. This is exactly the "automatic destabilizer" problem to which Bernanke and Campbell refer.

Nonetheless, for reasons I have elaborated elsewhere, I do not believe that the most likely result of corporate America's post-1982 borrowing binge is a cumulative series of defaults leading to debt deflation or worse. ${ }^{5}$ Instead, the more likely outcome is inflation. It is of limited value to contemplate such issues in the context of hypothetically holding monetary policy fixed, and it is clear that ranking Federal Reserve officials are as aware of the problem at issue here as anyone else. Forceful and sincere protestations of commitment to the anti-inflationary cause notwithstanding, it is highly unlikely that with today's debt burdens-and the default risks they entail should earnings shrink-the Federal Reserve would tolerate a recession comparable to that of 1973-75 or 1981-82.

To put the point in simple shorthand, the borrowing that American corporations have done in the 1980 s has shifted the short- and intermediate-run trade-offs confronting monetary policy, and it is implausible to expect policymakers to respond to events as they would have had that shift not occurred. But if the reason these enlarged debt burdens will not lead to debt deflation or worse is that they have effectively locked the Federal Reserve into a no-recession monetary policy, the record of inflation and business cycles since World War II gives little reason for confidence that the ultimate consequence of the corporate debt problem will not be the return of high inflation.

Lawrence H. Summers: Ben Bernanke and John Campbell examine the question of whether the American economy has an incipient corporate debt crisis. It is a rare macroeconomist who has not railed against the twin budget and trade deficits of recent years and the huge accumulation of American debt to foreigners. Bernanke and Campbell focus on a different and less clear-cut issue-whether growth in the outstanding stock of corporate debt constitutes a threat to financial stability. Their primary contribution is a thorough evaluation of evidence from the COMPUSTAT tapes on changes in the extent of leverage as reflected in

5. Benjamin M. Friedman, "Increasing Indebtedness and Financial Stability in the United States," in Federal Reserve Bank of Kansas City, Debt, Financial Stability, and Public Policy (FRBKC, 1986), pp. 27-53. 
ratios of corporate debt and interest payments to various denominators. Their conclusion is one of cautious concern. They point out that substantial costs are imposed by the excessive use of debt contracts, and they describe several plausible scenarios that could lead to unprecedentedly high levels of financial strain.

I have three observations, which I will first state briefly and then in more detail. First, there is less cause for concern about a corporate debt crisis than Bernanke and Campbell suggest. Economic problems are of different types. The productivity slowdown is profoundly important, but there are limits to what we can do about it. Promoting tourism is something we know how to do, but there is not much advantage to doing it. Corporate debt is to national economic policy about what disputes with Norway over fishing rights are to foreign policy. There is no apparent way to solve the problem, but it is not a very important one.

Second, if one wanted to worry about financial crises, there are grounds for concern much more serious than those suggested by Bernanke and Campbell. The dramatic increase in stock market volatility over the past several years provides the most serious basis for concern about the financial health of large corporations. But almost certainly of greater concern than the health of large industrial corporations like those on the COMPUSTAT tape is the health of small businesses, businesses that have recently gone private, and those involved in real estate.

Third, policymakers concerned about debt buildups could undertake reforms that would succeed in reducing corporate leverage, but those same reforms would probably raise the cost of capital facing American firms.

Bernanke and Campbell begin with a theoretical discussion of the reason why firms make use of debt contracts, emphasizing considerations of moral hazard and costly monitoring. They stress the possible inefficiencies of debt contracts in bankruptcy situations, and acknowledge only briefly the arguments of a long line of agency theorists, most recently Michael Jensen, that debt contracts are beneficial in limiting managerial discretion. ${ }^{1}$ Managers endowed with free cash flow are prone to expand companies, often inappropriately. Debt contracts subject management to the frequent discipline of the capital market.

1. Michael C. Jensen, "Takeovers: Their Causes and Consequences," Journal of Economic Perspectives, vol. 2 (Winter 1988), pp. 21-48. 
If one asks managers of profitable, prospering companies with debt equity ratios in the 0.3 range why they do not substitute some debt for equity, they virtually never refer to the possibility of future financial strain. Instead, they emphasize "loss of freedom," added scrutiny, and interference with managerial control as their reason for not taking on more debt.

The evidence is more than anecdotal; numerous studies suggest that most firms could significantly increase their total market value by substituting debt for equity. ${ }^{2}$ Event studies consistently reveal that companies that tie up cash flow by issuing debt show significant increases in total market value despite the moral hazard problems they risk. By contrast, companies that retire debt, or that issue equity, lose value. And, as is well known, investments financed from retentions are among the least profitable that firms make.

It may well be that what is fat from the point of view of shareholders generates important externalities for the economy. Bell Labs may be a good example here. And it may well be that bankruptcies have social consequences, so that private sector agents will run excessive risks. But these are not judgments that can be made on a priori grounds. The crucial point is that theoretical arguments conflict as to whether the free market will generate too much or too little debt.

Bernanke and Campbell also make much of the indexed-debt mystery. I have never found it so puzzling. We know that unanticipated inflation is terrible for firms. They lose something like 3 percent of value for every point of unanticipated inflation. ${ }^{3}$ It is hardly surprising to me that they do not exacerbate this uncertainty by offering bonds whose coupons would rise when inflation increased.

In trying to decide whether the United States has a corporate debt problem, Bernanke and Campbell focus on trends in debt ratios of various kinds. An analogy makes clear the logical insufficiency of this approach. Imagine that one observed that the average car was being driven faster in 1970 than in 1950,1960 , or 1965. Would such an

2. Michael C. Jensen, "Agency Costs of Free Cash-flow, Corporate Finance and Takeovers," American Economic Review, vol. 76 (May 1986, Papers and Proceedings, 1985), pp. 323-29.

3. For a discussion of inflation's impact on the valuation of corporate equities, see Lawrence H. Summers, "Inflation and the Valuation of Corporate Equities," Working Paper 824 (National Bureau of Economic Research, December 1981). 
observation imply that more risks were being taken on the highway? If speed limits had been raised or drivers had become more headstrong, the risks could be up. But drivers might be driving faster because roads were better or because better cars permitted more control at high speeds, in which case safety would have increased. Simply looking at speed without understanding the reason speed increased would be uninformative.

In just the same way, analysis of increases in debt ratios without analysis of why the increase took place is not very helpful. Three hypotheses about increasing debt present themselves. One, argued by Roger Gordon among many others, suggests that rising interest rates caused by high inflation during the late 1970s and early 1980s increased the tax advantage to corporate debt, because debt is deducted at a high rate whereas it is taxed at a lower rate ${ }^{4}$ This plausible theory would suggest that increased corporate debt is a cause for concern, just as increases in speed caused by reduced speeding enforcement would be. The theory is less strong on the dramatic substitution of debt for equity that has taken place in recent years.

An alternative hypothesis attributes the increase in debt to the development of the junk bond market and associated innovations. In this case, it is far from clear that debt is a source of concern. Innovations in institutional form may have made it possible for corporations to exploit the tax system more fully without incurring more contracting problems. Bernanke and Campbell correctly observe that only a small part of the increase in corporate debt can be traced to junk bonds. But this misses the point. The knowledge that firms in trouble now have access to credit markets will lead many firms to operate with more leverage than they once did.

The point may be argued in another way. Contracting problems, after all, inhere in structures, not labels. If the tax law permitted it, corporations would relabel all of their equity as "junior debt with income linked coupons" and deduct all dividends. This would raise debt ratios, but have no effect on stability or efficiency. Some part of the observed increase in debt must represent less dramatic innovations of this sort. I

4. Roger H. Gordon and Burton G. Malkiel, "Corporation Finance," in Henry J. Aaron and Joseph A. Pechman, eds., How Taxes Affect Economic Behavior (Brookings, 1981), pp. 131-92. 
think, for example, of leveraged buyouts where some investors hold both debt and equity in the firm.

A third hypothesis about debt buildup is that corporate debt ratios have risen because people have come to the correct view that the world is not as risky as they might previously have thought. As Bernanke and Campbell note, we have never had a corporate debt crisis. What is remarkable about the past six years is that despite the worst recession in fifty years, real interest rates that were once inconceivable, and huge structural changes, there have been no major corporate bankruptcies. Apologists for Latin American and farm debtors have made much of how bailouts are appropriate because what has happened to them was so unexpected. I think they are probably right to stress the surprising nature of recent events. Perhaps corporate managers and their bondholders have come to realize in the wake of the 1982 experience that corporations can hold more debt than one might initially have expected without facing critical liquidity or solvency problems.

I am agnostic about the relative importance of these explanations for increased corporate indebtedness. But without some serious effort to distinguish between them, an effort the paper does not make, the simple observation that debt ratios have risen does not justify concern over corporate debt problems.

If I wanted to fret about financial stability, I would worry about sectors other than those reflected in Bernanke and Campbell's data. Large corporations are a lightly levered sector of the economy. More problematic are the thrift institutions that are far under water and the money center banks that have a substantial fraction of their capital still tied up in problematic sovereign loans, and more of their capital tied up in leveraged buyout financing and in real estate and energy loans. Other examples are real estate developers who need the proceeds from past sales to be able to undertake new construction. Still others are the farm and energy-producing areas of the country.

It would be foolish to judge that it is inconceivable that monetary policy would ever turn so austere as to cause significant corporate bankruptcies. But so many other sectors of the economy are so much more fragile than the major nonfinancial corporate sector that it is unlikely that we would ever see a wave of corporate bankruptcies without first seeing a cataclysm in these other sectors. If such a cataclysm came, corporate bankruptcies would be more a symptom than a cause of economic problems. 
In fact, the way monetary policy is practiced makes it very unlikely that we will ever see a major wave of corporate bankruptcies. Monetary shocks in the United States do not just happen. Contractionary policies are sometimes pursued to reduce inflation. If, as Bernanke and Campbell argue, future monetary policy shocks will have greater effects than past ones, because they could trigger more bankruptcies, then the Federal Reserve will probably release the brakes more quickly than it has in the past, especially if it is concerned about the vulnerable areas I have just cited as well as about corporate bankruptcies.

I do, however, wish to record one source of concern about the corporate sector. Financial economics teaches us that equity may be thought of as an option on corporate cash flows. The value of equity should thus depend critically on the volatility of the underlying cash flows. Evidence on this is available-volatility is way up at least since October 19. I was sorry that Bernanke and Campbell did not make use of the readily available information on volatility measures in evaluating evidence on debt-equity ratios.

Those who are concerned about the problem of excess corporate leverage are rarely explicit about what they would do about it. Bernanke and Campbell do not really discuss this issue at all. Perhaps the most common suggestion is that tax policies need to be designed to reduce leverage.

This is a complex issue, as illustrated by the question of whether the 1986 tax reform act increased or decreased corporations' incentive to use debt finance. There are two views. The "public finance" view that dominated much of the political discussion during the tax reform debate holds that by reducing the corporate rate, the 1986 tax act reduced incentives for leverage. The "corporate finance" view, held by most academics in the finance area and many Wall Street practitioners, holds that the 1986 act increased incentives for leverage because corporate rates were reduced by less than top individual rates, and because increased capital gains taxes made equities less attractive to individual investors.

It is too early to tell who is right. My guess is that the corporate finance view is closer to being right. If so, we have an additional explanation for continuing increases in corporate debt ratios.

One could imagine policies that would clearly reduce the use of debt. For example, corporations might be allowed to deduct only part of their interest payments, or limits might be placed on allowable debt-equity 
ratios. But these policies would have substantial collateral costs that might outweigh any benefits in terms of financial stability. Most importantly, they would substantially raise the cost of capital facing American firms, thereby discouraging plant and equipment investments and longerterm projects more generally. Analyses of the large discrepancy between the cost of capital in the United States and in Japan typically point to the use of much higher leverage in Japan as a major factor contributing to their low cost of capital. ${ }^{5}$ Further, as I have argued above, such policies might well reduce the degree of capital market discipline imposed on managers. Finally, they would create strong incentives to various forms of merger activity directed at allowing firms to deduct more of their interest payments.

In summary, huge federal deficits and rapidly accumulating foreign debt are truly serious economic problems. It is extremely unlikely that corporate bankruptcies would become macroeconomically significant before a host of other problems reached enormous proportions. Given the limited capacities of the political process, policymakers should focus on the serious problem of the federal deficit rather than fretting about corporate debt problems that are probably not serious, and in any event cannot be addressed except through policy measures that would have substantial collateral costs.

\section{General Discussion}

Some panelists concurred with Lawrence Summers that financial innovations may allow the economy to support safely a higher stock of debt now than it has in the past. John Shoven agreed that junk bonds may not have the same implications for bankruptcy as ordinary bonds because, to the extent that junk bonds are closely held, bondholders will be more likely to renegotiate terms than to force bankruptcies. If so, safe interest coverage ratios will be higher for junk bonds than for ordinary debt. Robert Hall observed that the difference between debt and equity can be less important than their contractual terms suggest.

5. See, for example, George Hatsopoulos and Steve Brooks, "The Cost of Capital in the United States and Japan: An Update," paper presented at a conference on the cost of capital (John F. Kennedy School of Government, Harvard University, November 19-24, 1987). 
One reason is the characteristic of junk bonds that Shoven described, which, in effect, provides firms with bridge loans from their creditors when they are needed. Another is that firms under pressure from outside directors must continue to pay dividends even when the firm is having difficulties. Hence, in Hall's view, equity is much like debt, except for its tax treatment. James Poterba added that leveraged buyouts in recent years often involved "strip financing," whereby investors accepted different classes of debt as well as equity. So long as the original investors continue to hold these various claims, their incentives are much the same as if they had pure equity positions, but with the tax advantages of debt. Bruce Greenwald added that other, more subtle, changes may also have reduced the risk of bankruptcy. For instance, labor contracts, like debt, can be a significant fixed commitment of firms. But in recent years, workers have become more willing to accept flexible wage contracts, and firms have contracted out more work.

Shoven reasoned that tax changes over the decade have favored increasing debt. In the mid-1970s, equity generally had tax advantages over debt. An individual in the top tax bracket received, after taxes, only 30 cents of a dollar distributed as interest payments. On the other hand, 54 cents of a dollar of retained earnings remained after paying the corporate income tax, of which at least 35 cents remained after paying individual capital gains taxes. Thus, there was a 5 cent advantage to an individual in the top tax bracket to receiving a dollar of earnings as capital gains rather than interest payments. Now that the corporate tax rate is above the top individual rate, Shoven noted, a dollar of retained earnings is taxed more heavily than a dollar of interest payments, even ignoring the taxes on capital gains, giving debt a tax advantage over equity. However, Poterba pointed out that an increasing number of corporations reported tax losses over this same period and were therefore unable to use the corporate interest deductions, making equity relatively more attractive than debt for them. The tax effects on debt, he argued, cannot be determined unless the tax status of individual firms is taken into account.

Robert Hall discussed the possible benefits of debt in the context of what he called the "back-to-the-wall" theory of finance, whereby financial claims are made noncontingent on the performance of the firm. According to this theory, such financing creates the proper incentives for managers and thus increases efficiency, but at the same time increases 
the risk of a financial crisis. This moves the economy to higher levels of debt, higher mean output, and higher variance of output. But Hall noted that he had not seen empirical evidence supporting this theory. Indeed, real output has grown relatively smoothly since the early 1980 s, and evidence of efficiency gains in firms or industries that had leveraged themselves is meager. Greenwald argued that back-to-the-wall financing could have significant effects that were external to the corporations themselves. To the extent that there are external benefits to stabilizing the activities of corporations, such financing is costly to society in that it adds to corporate volatility. Furthermore, activities such as research and development, which have long payback periods as well as externalities, might be sacrificed in a more volatile corporate environment, causing a loss of overall productivity growth. Benjamin Friedman added that the increase in debt financing had not been associated with an increase in corporate investment.

The question of whether a corporate debt crisis is worth worrying about provoked a general discussion. William Brainard agreed with Summers's observation that other sectors are more endangered than the nonfinancial corporations the authors analyzed. But he took little comfort therein. If even major corporations are vulnerable to plausible macroeconomic developments, the still greater vulnerability of other sectors is reason for concern, not complacence. Poterba added that contagion effects might spread from bankruptcies in some firms. He recalled that when New York City was on the brink of bankruptcy, borrowing costs rose for other states and municipalities.

In response to Friedman's contention that the Federal Reserve would prevent a crisis by easing monetary policy, Ben Bernanke questioned whether such an expansionary policy would work fast enough to prevent a collapse. James Tobin was skeptical that the Federal Reserve would respond to liquidity problems of nonfinancial corporations, as distinct from financial institutions. Summers argued that an inflationary bias in monetary policy would not solve the bankruptcy problem, but would, over time, increase the use of debt and thus exacerbate it.

Friedman criticized the authors' cross-sectional regressions explaining debt-asset ratios as a function of the market's valuation of equity. He reasoned that corporate reorganizations and takeovers may have caused both the overvaluation of equity and the overuse of debt. 
Several individuals suggested improvements in the authors' treatment of bankruptcy risk. Brainard suggested that a fuller analysis of the market value of the firm relative to the value of its debt obligation required estimating that ratio over a distribution of future earnings relative to contractual payments. He also supported the authors' attention to liquidity constraints, observing that because financial markets are far from perfect predictors, bankruptcy could occur because of an inability to meet current obligations even if the firm appeared viable in the long run. Alan Blinder argued that real interes، rates are more appropriate than nominal rates for comparing interest burdens because they account for the evaporation of principal due to inflation. However, Friedman defended the use of nominal rates, noting that cash flow obligations are nominal. Although inflation would reduce their value over time, it would not help avoid a liquidity crisis that might emerge in the short term. In this connection, Summers observed that coverage calculations ought to take into account the obligations to repay principal as well as interest. 